\title{
DOENÇAS FÚNGICAS DE SOLO NA CULTURA DA BATATA: SINTOMAS, ETIOLOGIA E MANEJO
}

\author{
J.G. Töfoli, R.J. Domingues, J.T. Ferrari \\ Secretaria de Agricultura e Abastecimento do Estado de São Paulo, Instituto Biológico, Centro de Pesquisa de \\ Sanidade Vegetal, Av. Cons. Rodrigues Alves, 1252, CEP 04014-900, São Paulo, SP, Brasil. \\ E-mail: tofoli@biologico.sp.gov.br
}

\begin{abstract}
RESUMO
As doenças fúngicas de solo podem ser problemáticas e causar sérios prejuízos à cultura da batata. Elas podem afetar a germinação, a emergência, o desenvolvimento vegetativo e o ciclo da cultura, assim como reduzir a produtividade e a qualidade dos tubérculos. Além do difícil controle, os agentes causais dessas doenças são capazes de produzir estruturas de resistência que podem perpetuá-los por longos períodos no solo, inviabilizando, muitas vezes, o cultivo da batata em áreas infestadas. $O$ manejo deve integrar medidas de controle como: o uso de sementes sadias, a rotação de culturas, a adubação equilibrada, o plantio de cultivares resistentes/tolerantes, o uso de fungicidas registrados e o controle biológico.
\end{abstract}

PALAVRAS-CHAVE: Solanum tuberosum, fungos, fungicidas, controle biológico.

\section{ABSTRACT \\ SOIL-BORNE FUNGAL DISEASES IN THE POTATO CROP: SYMPTOMS, ETIOLOGY AND MANAGEMENT.}

Soil fungal diseases can be problematic and cause serious damage to the potato crop. These can directly affect germination, emergence, vegetative development, culture cycle as well as reduce the productivity and quality of tubers. Besides the difficult control, the causal agents of these diseases are capable of producing structures of resistance that can perpetuate them for long periods in the soil, often making it impossible to grow potatoes in infested areas. Management should integrate control measures such as the use of healthy seeds, crop rotation, balanced fertilization, planting of resistant/tolerant cultivars, use of registered fungicides and biological control.

KEYWORDS: Solanum tuberosum, fungi, control, fungicides, biological control. 
Considerada como o mais precioso tesouro dos povos andinos, a batata (Solanum tuberosum $\mathrm{L}$ ) transformou hábitos, culturas e costumes graças à sua excelência como alimento, adaptabilidade e elevado potencial produtivo. Vista como um dos pilares da alimentação humana, essa solanácea é uma fonte considerável de carboidratos, fósforo, potássio, vitaminas do complexo $B$ e $C$, proteínas de boa qualidade, fibra alimentar e outros nutrientes, podendo ser consumida "in natura" ou industrializada, nas mais diferentes formas.

No Brasil, a batata não é considerada um alimento básico, porém é a olerácea que ocupa a maior área cultivada. A produção brasileira, em 2018, foi de 3,9 miIhões de toneladas, colhida em uma área de 127 mil hectares, com uma produtividade média de $30 \mathrm{t} / \mathrm{ha}$. As regiões Sudeste e Sul são responsáveis por praticamente $90 \%$ da produção nacional, sendo Minas Gerais, São Paulo, Paraná e Rio Grande do Sul os principais estados produtores. Atualmente, a cadeia produtiva da batata apresenta características empresariais bem definidas, avanços tecnológicos constantes e gerenciamento avançado de todo o processo produtivo e comercialização.

As doenças fúngicas de solo podem ser limitantes e causar sérios prejuízos à cadeia produtiva da batata. Elas podem afetar de forma direta a germinação, a emergência, o desenvolvimento vegetativo e o ciclo da cultura, assim como reduzir a produtividade e a qualidade de tubérculos.
O presente artigo visa descrever a sintomatologia, a etiologia e o manejo das principais doenças fúngicas de solo observadas na bataticultura brasileira.

\section{RIZOCTONIOSE}

Rhizoctonia solani J.G. Kühn.

A rizoctoniose ou crosta-negra é uma doença de ocorrência generalizada na cultura da batata, sendo comum em áreas úmidas e intensamente cultivadas.

Germinação lenta, presença de lesões castanho-avermelhadas em hastes jovens, redução do estande, crescimento desigual, desenvolvimento limitado das plantas, amarelecimento, enrolamento de folhas, emissão de tubérculos aéreos, tubérculos pequenos, deformados, partidos, enrugados e associados a escleródios são os sintomas típicos da doença. $\mathrm{O}$ termo crosta negra refere-se à presença de escleródios que se formam e permanecem aderidos à superfície dontubérculo. Eles posuem coloração marrom-escura a negra, apresentam tamanhos e formatos variáveis e são formados pelo enovelamento do micélio do fungo.

O agente causal Rhizoctonia solani J.G. Kühn, possui micélio marrom a ocre, hifas septadas e ramificações laterais em ângulo reto e pode ser visualizado sobre a superfície do tubérculo, com auxílio de uma lupa. A sua disseminação ocorre principalmente através de batata-semente infectada, máquinas, ferramentas e implementos agrícolas contaminados e pelo escoamento de água de superfície proveniente de chuvas e irrigação excessivas. 
A rizoctoniose na cultura da batata é causada principalmente pelos grupos de anastomose AG-3 e AG-4. O grupo AG-3 causa podridões radiculares em batata, tomate e berinjela (subgrupo AG-3 PT) e manchas foliares em fumo (subgrupo AG-3 TB). O grupo AG-4 é menos específico, podendo causar podridão de sementes, tombamento de pré e de pósemergência e, em algumas situações, podridão de raízes em culturas como soja, feijão, amendoim, tomate, melão, melancia, espinafre, pimentão e brócolis.

As fases de maior suscetibilidade à doença estendem-se do plantio até a amontoa. Porém, o fungo também pode afetar os brotos de batatas-semente armazenadas.

A doença é favorecida por solos argilosos, frios, úmidos, mal drenados, matéria orgânica mal decomposta, plantios profundos e temperaturas que podem variar de 18 a $25^{\circ} \mathrm{C}$.

O fungo pode sobreviver no solo por longos períodos, mantendo-se na forma de escleródios ou micélio ou colonizando restos de cultura. Quando as condições climáticas são favoráveis, os escleródios germinam e infectam as gemas e as hastes recém-emergidas do solo.

Além das culturas citadas anteriormente, os grupos de anastomose de $R$. solani associados à cultura da batata podem também afetar plantas invasoras como: joá-de-capote (Nicandra physaloides L.) beldroega (Portulaca oleracea L.), caruru (Amaranthus deflexus L.) e maria-pretinha (Solanum americanum L.)
Para o manejo da rizoctoniose recomenda-se a integração de medidas como:

- Plantio de batata-semente sadia;

- Evitar o plantio em áreas com histórico recente da doença;

- Em áreas intensamente cultivadas eliminar possíveis "pés de grade", com o objetivo de favorecer a aeração e a drenagem do solo, evitando o acúmulo de umidade nas camadas superficiais;

- Realizar o plantio de batata-semente, entre 5 e $7 \mathrm{~cm}$, para favorecer a rápida germinação e emergência das plantas;

- Evitar o plantio em solos argilosos (pesados) ou excessivamente úmidos;

- Plantio de cultivares com algum nível de tolerância como: Vivaldi, Bailla, Chipie, Colorado, Gredine, Opaline, Soleia, Markies, Voyager, Sinora, Novella e Innovator;

- Realizar a adubação com base na análise de solo. Excesso de nitrogênio e matéria orgânica pode tornar as hastes mais tenras e mais suscetíveis à doença. Níveis adequados de cálcio, fósforo e silício podem tornar as brotações mais resistentes a infecções;

- Promover o plantio e a incorporação de adubos verdes. $\mathrm{O}$ aumento da matéria orgânica favorece o desenvolvimento de uma microflora benéfica que, ao competir por alimento e espaço, reduz a população do patógeno no solo. Além disso, a decomposição dos adubos verdes libera compostos capazes de reduzir a capacidade competitiva do patógeno; 
- Tratamento de sementes e/ou a aplicação de fungicidas registrados no sulco de plantio e na amontoa;

- Controle biológico. Formulações de Trichoderma harzianum aplicados no tratamento de sementes ou no sulco de plantio podem reduzir a severidade da doença nas hastes e a presença de escleródios nos tubérculos. Pesquisas com formulações de Bacillus subtilis também têm sido promissoras para o controle da rizoctoniose em batata;

- Realizar o manejo adequado da irrigação para evitar acúmulo de umidade no solo;

- Evitar ferimentos nas hastes durante as operações de amontoa e tratos culturais;

- Eliminar da área restos de cultura, plantas voluntárias, tubérculos remanescentes da colheita e hospedeiros alternativos do fungo;

- Evitar o uso de implementos, tratores, ferramentas, botas e caixas utilizadas em áreas infestadas. Realizar a lavagem e a desinfestação dos mesmos antes de executar os tratos culturais em áreas livres da doença;

- Evitar atrasos e ferimentos nos tubérculos na colheita;

- Eliminar e destruir tubérculos doentes;

- Promover condições adequadas de temperatura, umidade, circulação de ar e higiene durante o armazenamento de batata-semente e tubérculos.

\section{SARNA PRATEADA}

Helminthosporium solani Durieu \& Mont.

A sarna prateada afeta os tubérculos no campo ou no armazenamento, provocando o aparecimento de manchas claras superficiais que, ao evoluírem, apresentam um aspecto circular, escuro e indefinido. Posteriormente, os tubérculos apresentam menor peso e enrugamento superficial, devido à perda de água. A casca apresenta-se alterada, com aspecto seco, áspero e brilho prateado, principalmente quando úmida ou molhada. Quando a colheita é realizada em condições de alta umidade, as manchas podem apresentar-se recobertas por conidióforos e conídios do fungo. No armazenamento em câmaras frias, a doença causa a desidratação de tubérculos e pode estar associada a patógenos dos gêneros Fusarium, Pectobacterium e Dickeya.

Helminthosporium solani possui micélio septado, ramificado e hialino. Os conidióforos são simples, longos e septados. Apresentam coloração castanho-escura, são redondos na base e afilados para o final. Eles variam de 15 a $64 \mu \mathrm{m}$ de comprimento e de 4 a 8 $\mu \mathrm{m}$ de largura e podem apresentar até 8 septos transversais.

A sarna prateada afeta apenas os tubérculos, não ocorrendo em outros órgãos aéreos ou subterrâneos da planta. A doença raramente interfere na produtividade, porém pode afetar de forma significativa o valor comercial de tubérculos lavados. 
A sarna prateada é transmitida principalmente por batatas-semente infectadas, sendo comum a sua presença em sementes importadas. A doença é favorecida por temperatura e umidade elevadas. $O$ fungo penetra nos tubérculos pelas lenticelas ou pela epiderme, antes da colheita, e continua seu desenvolvimento durante o armazenamento. A doença pode ser intensificada pelo atraso na colheita.

\section{As medidas de controle recomenda- das para o manejo da sarna prateada} são:

- Plantio de batata-semente sadia;

- Optar por cultivares com algum nível de resistência à doença. A cultivar Ludmilla é considerada tolerante à sarna-prateada;

- Plantio em solos drenados e bem preparados;

- Após a retirada da câmara fria, permitir que os tubérculos sequem em ambiente com baixa umidade antes do plantio;

- Evitar plantios sucessivos de batata na mesma área;

- Controle biológico. Estudos têm demonstrado que Bacillus subtilis possui potencial de reduzir a sarna-prateada em condições de armazenamento;

- A colheita deve ser realizada logo após a secagem das ramas e o completo amadurecimento dos tubérculos. Deve-se evitar ainda que a colheita ocorra em períodos de elevadas temperaturas e umidade e que se produzam ferimentos nos tubérculos durante o processo;

- Eliminar e destruir tubérculos doentes, plantas voluntárias de batata e tubérculos remanescentes no campo;

- Promover condições adequadas de temperatura, umidade, circulação de ar e higiene durante o armazenamento de batata-semente e tubérculos.

\section{SARNA PULVERULENTA}

Spongospora subterranea sp. subterranea (Wallr.) Lagerh.

A sarna pulverulenta afeta diretamente os tubérculos, reduzindo o seu valor comercial ou inviabilizando-os para o mercado. A doença já foi observada em algumas regiões produtoras brasileiras, sendo sempre associada ao plantio de batata-semente infectada.

Os sintomas iniciais da doença manifestam-se através de pequenas manchas de cor clara na superfície do tubérculo. A infecção leva à hipertrofia e hiperplasia das células hospedeiras e ruptura dos tecidos, originando pústulas abertas, escuras, arredondadas e com bordas irregulares compostas por fragmentos da epiderme. No centro, as lesões são deprimidas, apresentando tecidos irregulares e esponjosos. Nas raízes, formam-se galhas escuras e enrugadas, que reduzem o desenvolvimento das plantas. As lesões causadas pela doença favorecem a entrada de outros agentes causadores de podridões como os Gêneros Fusarium, Pectobacterium e Dickeya, que podem dificultar o diagnóstico. 
Spongospora subterranea sp. subterranea pertence ao Reino Chromista, Filo Cercozoa, Classe Phytomyxea, Ordem Plasmodiophorales. Associados às lesões, encontram-se cistossoros e zoósporos. Os cistossoros são ovoides, irregulares, com 19-85 $\mu \mathrm{m}$ de diâmetro. Os esporos são poliédricos, com 3,5-4,5 $\mu \mathrm{m}$ de diâmetro, com paredes lisas, finas e amareladas. Os zoósporos responsáveis pelo processo de infecção são ovoides, biflagelados e possuem a capacidade de se movimentarem em água livre. Os cistossoros atuam como estruturas de resistência, que permitem ao patógeno sobreviver no solo por períodos de 3 a 10 anos, e são facilmente disseminados por tubérculos infectados, escorrimento de água de superfície (chuvas e irrigação) e solo infestado aderido a ferramentas, implementos, botas etc. Além de causar a sarna pulverulenta, $\mathrm{S}$. subterranea $\mathrm{sp}$. subterranea pode ser vetor do Potato mop-top virus (PMTV).

A sarna-pulverulenta é favorecida por elevada umidade no solo, temperaturas frias $\left(11\right.$ a $\left.18^{\circ} \mathrm{C}\right)$ e $\mathrm{pH}$ na faixa de 4,7 a 7,6 . A infecção é mais comum nos estágios iniciais de formação de tubérculos, mas pode ocorrer em todos os estágios do desenvolvimento. Não se conhecem cultivares resistentes à doença.

Entre os hospedeiros de $S$. subterranea sp. subterranea descritos pela literatura destacam-se o tomate (Solanum lycopersicum), o pimentão (Capsicum annuum), o nabo (Brassica rapa subsp. rapa), a canola (Brassi canapus), o agrião (Nasturtium sp.) e plantas invasoras como maria-pretinha (Solanum americanum), Solanum sp. e figueira-do-inferno (Datura stramonium).

\section{As principais medidas recomendadas} para o controle da sarna pulverulenta são:

- A exclusão através do plantio de batata-semente sadia é uma das medidas mais importantes para evitar a entrada e a disseminação da doença;

- Evitar o plantio em solos densos e sujeitos ao acúmulo de umidade;

- Evitar altos níveis de umidade nos primeiros 50 dias do ciclo. Em condições extremas, a irrigação deve ser suspensa para evitar que a doença seja disseminada por toda a cultura;

- Eliminar plantas voluntárias, restos de cultura e hospedeiros intermediários;

- Estudos têm demonstrado que a adição de fontes de cálcio, enxofre e zinco no solo pode reduzir a severidade da doença;

- Rotação de culturas. Evitar o plantio de batata e outros hospedeiros suscetíveis em áreas com histórico da doença por um período de 5 a 10 anos;

- Aplicação de fungicidas registrados conforme recomendações do fabricante;

- Eliminar e destruir tubérculos infectados;

- Evitar ferimentos nos tubérculos durante a colheita; 
- Não permitir a circulação de implementos e pessoas provenientes de áreas infestadas;

- Realizar a lavagem e a desinfestação de implementos, ferramentas, botas e caixas utilizadas em áreas infestadas;

- Promover condições adequadas de temperatura, umidade, circulação de ar e higiene durante o armazenamento de batata-semente e tubérculos.

\section{MURCHA DE FUSARIUM E PODRIDÃO SECA}

Fusarium spp.

A murcha de Fusarium é uma das doenças mais comuns na cultura da batata. A doença pode causar falhas na germinação, morte de plantas, perda de vigor, queda significativa de produtividade e qualidade de tubérculos. A podridãoseca durante o armazenamento pode causar a depreciação e o descarte significativo de tubérculos. A doença pode causar perdas de $25 \%$ no campo e de $60 \%$ durante o armazenamento.

Várias espécies do gênero Fusarium podem causar danos à cultura da batata como: Fusarium solani (Mart.) Sacc., Fusarium avenaceum (Fr.:Fr.) Sacc., Fusarium solani f. sp. eumartii (C.W. Carp.) W.C. Snyder \& H.N. Hansen e Fusarium oxysporum f. sp. tuberosi Snyder et Hansen. As espécies citadas possuem micélio vigoroso, que pode variar do branco ao roxo, apresenta hifas septadas e pode produzir macro e microconídios. Apresenta, ainda, estruturas de resistência denominadas clamidósporos, que podem perpetuar o patógeno no solo por longos períodos.
A doença é caracterizada pela murcha progressiva das plantas, escurecimento externo das hastes e descoloração dos tecidos vasculares de hastes e tubérculos. Clorose, bronzeamento das folhas, formação de tubérculos aéreos e escurecimento das gemas (olhos negros) também são sintomas típicos.

O sintoma de podridão-seca de tubérculos é observado durante o armazenamento e está associado principalmente às espécies $F$. solani e $F$. avenaceum. Caracteriza-se pela formação de lesões e pelo apodrecimento generalizado dos tubérculos, escurecimento dos tecidos internos e presença de bolor branco-rosado sobre as lesões. A doença afeta diretamente a aparência dos tubérculos e reduz o rendimento, devido ao descarte de tubérculos doentes. Em geral, a infecção ocorre por meio de ferimentos na colheita e os sintomas se tornam evidentes durante o armazenamento. Aassociação com outros patógenos como Helminthosporium solani e bactérias dos gêneros Pectobacterium e Dickeya pode tornar as perdas mais significativas.

As diferentes espécies de Fusarium podem sobreviver no solo por longos períodos, infectando plantas e tubérculos. Plantio em solos infestados, uso de sementes infectadas e armazenamento inadequado dos tubérculos favorecem a doença. No campo, o fungo penetra através das raízes, colonizando rapidamente o sistema vascular. Nos tubérculos, o fungo penetra através de ferimentos causados durante a colheita, sendo os sintomas observados durante o armazenamento. 
A doença é favorecida por temperaturas ao redor de $25^{\circ} \mathrm{C}$, umidade relativa em torno de $60-75 \%$ e solos ácidos.

\section{Para o manejo da murcha de Fusarium e podridão seca recomenda-se:}

- Evitar o plantio em área com histórico recente da doença;

- Plantio de sementes sadias;

- Quando possível optar por cultivares com algum nível de resistência. As cultivares Asterix e Markies são consideradas tolerantes à doença;

- Tratamento de sementes com fungicida registrado;

- Uso de adubação equilibrada e pH adequado (6,0-6,5). Utilizar adubos de liberação lenta. Elevados níveis de adubação nitrogenada podem aumentar a suscetibilidade à doença, enquanto que níveis adequados de cálcio, fósforo e potássio podem reduzi-la;

- Controle biológico - trabalhos de pesquisa têm demonstrado que Trichoderma spp. possui elevado potencial de reduzir a incidência e a severidade da doença;

- Evitar ferimentos nas plantas durante os tratos culturais;

- Irrigação equilibrada - plantas de batatas ficam mais suscetíveis à doença em condições de estresse hídrico;

- Colher tubérculos completamente maduros, evitando sempre ferimentos durante a colheita e o armazenamento;

- Eliminar tubérculos remanescentes no campo, plantas voluntárias e hospedeiras alternativas e tubérculos doentes;
- Lavar e desinfestar implementos, ferramentas, equipamentos de lavagem e classificação;

- Promover condições adequadas de temperatura, umidade, circulação de ar e higiene durante o armazenamento de batata-semente e tubérculos.

\section{MURCHA DE VERTICILLIUM}

Verticillium dahliae Kleb.

No Brasil, a murcha de Verticillium é considerada uma doença esporádica na cultura da batata, sendo relatada principalmente nos estados de São Paulo e Rio Grande do Sul.

Os sintomas da murcha de Verticillium são caracterizados pelo amarelecimento e seca de folhas e folíolos, murcha progressiva, escurecimento dos vasos condutores, necroses em hastes e morte de plantas. Tubérculos afetados podem apresentar descoloração vascular castanha semelhante às hastes. A doença pode causar redução significativa na produtividade e no tamanho dos tubérculos.

Verticillium dahliae apresenta micélio hialino septado e ramificado, conídios simples unicelulares ovais e hialinos. Trata-se de um fungo polífago, que pode parasitar mais de 400 hospedeiros, incluindo espécies herbáceas anuais (hortaliças, ornamentais, cereais etc.) e perenes (frutíferas, florestais etc.). Ele pode sobreviver por longos períodos no solo, associado à matéria orgânica ou por meio de estruturas de resistência denominadas microescleródios. 
Verticillium dahliae infecta a planta através das raízes e coloniza o sistema vascular, resultando em uma menor absorção de água e nutrientes, que gera, ao longo do tempo, a queda de vigor, murcha progressiva e morte de plantas. A doença é mais severa em plantas mal nutridas e em situações de estresse, favorecida por constantes mudanças climáticas e falta de água. $\mathrm{O}$ agente causal pode sobreviver no solo associado à matéria orgânica, na forma de microescleródios ou ainda no interior de tubérculos.

A doença é favorecida por temperaturas que variam de 21 a $28{ }^{\circ} \mathrm{C}$ e alta umidade do solo. Ela pode ocorrer isolada ou em complexo com outras doenças como canela-preta, murcha de Fusarium e nematoides. Os ferimentos causados por nematoides no sistema radicular e tubérculos podem aumentar a incidência e a severidade da doença.

A prevenção é a melhor maneira de controlar essa doença potencialmente grave. Práticas que evitem a entrada do patógeno na área e medidas integradas de controle devem ser observadas com rigor.

\section{Para o manejo da murcha de Verti- cillium recomenda-se:}

- Plantio de batata-semente sadia;

- Adubação equilibrada. O uso de nitrogênio amoniacal e níveis adequados de manganês, cobre e zinco podem reduzir a severidade da doença;

- Rotação de culturas com gramíneas el ou adubos verdes por 3 a 4 anos;
- Evitar irrigações excessivas e injúrias nas plantas durante os tratos culturais;

- Eliminar e destruir os restos de cultura e plantas voluntárias;

- Manejo adequado dos nematoides;

- Eliminar tubérculos remanescentes, plantas voluntárias e hospedeiras alternativas tais como figueira-do-inferno (Datura stramonium), maria-pretinha (Solanum americanum), fisális (Physalis sp.), joá-vermelho (Solanum incarceratum), jurubeba (Solanum paniculatum);

- Em áreas afetadas pela doença, antecipar a colheita, com o objetivo de reduzir as perdas e impedir o aumento do inóculo na área;

- Lavar e desinfestar botas, equipamentos e implementos utilizados em áreas infestadas.

- Promover temperatura, umidade e circulação de ar e higiene adequada durante o armazenamento de batata-semente e tubérculos.

\section{MOFO BRANCO}

Sclerotinia sclerotiorum (Lib.) de Bary.

O mofo branco ocorre em áreas intensamente cultivadas e sujeitas à alta umidade e temperaturas amenas. A doença encontra as condições favoráveis para o seu desenvolvimento nas safras de inverno, sendo frequente a sua ocorrência em áreas de pivô central infestadas.

Os sintomas da doença se caracterizam por lesões úmidas, recobertas de 
micélio branco e escleródios negros, que afetam folhas e hastes. Nas hastes, as lesões tendem ao anelamento, culminando com a murcha e morte das mesmas. A doença causa também a destruição da medula interna do caule, que se torna parda e repleta de escleródios negros no seu interior.

Sclerotinia sclerotiorum apresenta micélio vigoroso, de coloração branca e produz estruturas de resistência denominadas escleródios. Esses são negros, grandes (20-10 mm de diâmetro), lisos, com formatos que variam do arredondado ao irregular. Os escleródios, além de germinarem diretamente no solo produzindo micélio, possuem a capacidade de produzir apotécios em condições específicas, relacionados ao ascomiceto Peziza sclerotiorum, fase teleomórfica do patógeno. A formação de micélio a partir dos escleródios ocorre em condições de alta umidade e temperaturas na faixa de 21 a $25{ }^{\circ} \mathrm{C}$. Ele cresce na superfície do solo, colonizando inicialmente folhas senescentes próximas do solo e em seguida tecidos sadios. Os apotécios, por sua vez, são corpos de frutificação semelhantes a pequenos cogumelos, que produzem milhões de ascósporos que são ejetados e, em seguida, dispersos pelo vento ou água. Esses, em contato com a planta, germinam e dão início à infecção. Os ascósporos podem sobreviver por até duas semanas antes de iniciar uma infecção. Os apotécios são produzidos em condições de alta umidade e temperaturas em torno de 11 a $20^{\circ} \mathrm{C}$. Os escleródios podem sobreviver no solo por períodos de
6 a 8 anos, sendo a sua sobrevivência intimamente relacionada com o tipo de solo, $\mathrm{pH}$, cultura anterior, sua localização no perfil do solo, umidade, temperatura e de presença de micro-organismos que causam sua degradação.

S. sclerotiorum tem um amplo espectro de plantas hospedeiras, sendo relatada em mais de 350 espécies.

\section{As principais medidas recomendadas para o manejo do mofo branco são:}

- Evitar o plantio em áreas com histórico recente da ocorrência da doença;

- Preparo adequado da área, evitando a formação de pés de grade e o acúmulo de umidade no solo;

- Plantio de cultivares com menor desenvolvimento vegetativo;

- Evitar plantio adensado;

- Rotação de culturas por períodos mínimos de 4 anos, evitando o plantio de espécies suscetíveis como feijão, tomate, soja e girassol, entre outras;

- Irrigação controlada nos períodos críticos da doença;

- Adubação equilibrada. A doença é favorecida pelo excesso de adubação nitrogenada. Nessas condições, a cultura apresenta desenvolvimento vegetativo excessivo, o que favorece a formação de microclima favorável ao desenvolvimento da doença;

- Aplicação de fungicidas registrados;

- Controle biológico. Estudos têm demonstrado que Trichoderma spp. pode reduzir o mofo-branco; 
- Eliminar e destruir restos de culturas infestados;

- Impedir o tráfego de implementos e pessoas provenientes de áreas infestadas;

- Lavar e desinfestar ferramentas, implementos e botas.

\section{PODRIDÃO AQUOSA}

Globisporangium spp.

A podridão aquosa pode estar associada às espécies Globisporangium ultimum (Trow) Uzuhashi, Tojo \& Kakish (Pythium. Ultimum Trow); Globisporangium splendens(HansBraun) Uzuhashi, Tojo \& Kakish. (Sin. Pythium splendens Hans Braun), Globisporangium sylvaticum (W.A. Campb. \& F.F. Hendrix) Uzuhashi, Tojo \& Kakish. (Sin. Pythium sylvaticum W.A. Campb. \& F.F. Hendrix), Pythium aphanidermatum (Edson) Fitzp., e Pythium deliense Meurs. No Brasil, a doença foi observada pela primeira vez no estado de São Paulo, em 2006.

Os sintomas iniciais são caracterizados por pequenas lesões escuras, que se observam sobre a superfície dos tubérculos. Os tubérculos afetados podem apresentar apodrecimento generalizado e eliminar um vazamento aquoso, geralmente sem odor fétido. Os tubérculos infectados, quando cortados, assumem rapidamente uma coloração negra. A doença pode, ainda, gerar estandes irregulares, devido à baixa emergência e, em algumas circunstâncias, causar a murcha de plantas no campo. A doença pode, também, causar sérias perdas no armazenamento e na comercialização. A podridão-aquosa é transmitida principalmente por batata-semente infectada.

A doença está sempre associada a temperaturas de 25 a $30^{\circ} \mathrm{C}$ e alta umidade próximas à colheita.

Globisporangium spp. pode sobreviver no solo por longos períodos, graças à produção de estruturas de resistência, denominadas oósporos.

\section{As principais medidas recomendadas} para o manejo da podridão aquosa são:

- Plantio de sementes sadias;

- Plantio em áreas drenadas e não sujeitas ao acúmulo de umidade;

- Adubação equilibrada. O uso exagerado de adubação nitrogenada favorece o crescimento vegetativo excessivo e a formação de tecidos tenros mais suscetíveis à infecção. Níveis adequados de fósforo, cálcio e silício e $\mathrm{pH}$ acima de 7 podem reduzir a doença;

- Irrigação equilibrada, principalmente nas semanas que antecedem a colheita;

- A colheita não deve ser realizada em dias muito quentes e úmidos. Os tubérculos devem estar maduros e a pele completamente definida;

- Evitar que os tubérculos fiquem expostos ao sol por muito tempo antes do armazenamento;

- Evitar ferimentos durante a colheita, transporte e beneficiamento; 
- Os tubérculos doentes devem ser eliminados e destruídos;

- Rotação de culturas por no mínimo 4 anos, para redução do inóculo na área;

- Promover condições adequadas de temperatura, umidade, circulação de ar e higiene durante o armazenamento de batata-semente e tubérculos;

- Lavar e desinfestar caixas, equipamentos de lavagem e classificação.

\section{OLHO PARDO}

Calonectria brassicae (Panwar \& Bohra)

Lombard, M.J. Wingf. \& Crous. Sin.

Cylindrocladium clavatum Hodges \&

L.C. May.

O olho pardo é caracterizado por lesões irregulares levemente deprimidas e de coloração parda a negra. O centro das lesões pode ser mais claro e recoberto por conídios e conidióforos do fungo. A doença afeta exclusivamente os tubérculos, reduzindo de forma significativa o valor comercial dos mesmos.

Calonectria brassicae possui conídios cilíndricos, hialinos e unisseptados, com 37,6-47,9 x 3,4-5,6 $\mu \mathrm{m}$ de diâmetro. O gênero Calonectria agrupa parasitas facultativos que, devido à capacidade de produzir microescleródios, tanto em meio de cultura artificial, como no solo e sobre os hospedeiros, sobrevivem às mais adversas condições ambientais. As estruturas infectivas germinam e penetram diretamente pelas lenticelas presentes na superfície dos tubérculos, não sendo necessária a existência de ferimentos.
O olho pardo é favorecido por temperaturas ao redor de $25^{\circ} \mathrm{C}$ e alta umidade. O processo infeccioso ocorre no campo, porém os sintomas, na maioria das vezes, são observados somente na pós-colheita. A associação da doença com outros patógenos, como Helminthosporium solani, Fusarium spp., Pectobacterium spp. e Dickeya spp. pode causar perdas significativas durante o armazenamento e a comercialização.

A doença é observada com maior frequência em solos de cerrado, principalmente em áreas cultivadas anteriormente com soja, amendoim, ervilha, pimentão, pimenta, mandioca e eucalipto, que também são hospedeiros do patógeno. Na cultura da batata, o olho-pardo é relatado apenas no Brasil.

\section{As principais medidas recomendadas para o controle do olho pardo são:}

- Plantio de sementes sadias;

- Evitar o plantio em área com histórico recente da doença;

- Optar por cultivares com algum nível de resistência. Em estudo com inoculação do agente causal em tubérculos de batata as cultivares Caesar, Ibituaçú e Asterix foram as mais tolerantes, enquanto que Ágata e Itararé as mais suscetíveis;

- Rotação de culturas;

- Colher tubérculos com a pele firme;

- Evitar ferimento nos tubérculos durante a colheita e armazenamento;

- Eliminação e destruição de tubérculos doentes; 
- Lavar e desinfestar caixas, equipamentos de lavagem e de classificação;

- Promover condições adequadas de temperatura, umidade, circulação de ar e higiene durante $o$ armazenamento de batata-semente e tubérculos.

\section{CONTROLE QUÍMICO}

O uso de fungicidas registrados para o controle de doenças fúngicas de solo na cultura da batata deve ser realizado dentro de programas de controle integrado e deve seguir todas as recomendações do fabricante quanto à dose, estádio fenológico, tecnologia de aplicação, uso de equipamento de proteção individual (EPI), armazenamento de produtos e descarte de embalagens.

O uso de fungicidas no controle da rizoctoniose, murcha de Fusarium e sarna pulverulenta pode ser realizado através do tratamento de sementes, aplicação em sulco ou, ainda, através de aplicação nas hastes antes da amontoa. $O$ tratamento apresenta caráter preventivo e foca diretamente o patógeno presente no solo ou associado à batata-semente. Em áreas com histórico de mofo-branco, as aplicações de fungicidas devem começar assim que se inicie o fechamento da cultura.

Para evitar a ocorrência de fungos resistentes a fungicidas recomenda-se que produtos com mecanismo de ação específico sejam utilizados de forma alternada ou formulados com produtos multissítios e que se evite o uso repetitivo de produtos com o mesmo mecanismo de ação.

Os fungicidas recomendados para o controle de doenças fúngicas de solo na cultura da batata encontram-se caracterizados no Quadro 1.

Quadro 1. Ingrediente ativo, alvo, mobilidade, mecanismo de ação e risco de resistência dos fungicidas registrados no Brasil para o controle de doenças fúngicas de solo na cultura da batata.

\begin{tabular}{|c|c|c|c|c|}
\hline Ingrediente ativo* & Doença & Mobilidade na planta & Mecanismo de ação & Risco de resistência** \\
\hline pencicuron & rizoctoniose & contato & divisão celular & desconhecido \\
\hline fludioxonil & rizoctoniose & contato & transdução do sinal & baixo a médio \\
\hline flutolanil & rizoctoniose & translaminar & inibidor da respiração & médio a alto \\
\hline trifluzamida & rizoctoniose & sistêmico & $\begin{array}{c}\text { inibidor da respiração } \\
\text { complexo II }\end{array}$ & médio \\
\hline $\begin{array}{l}\text { tiofanato } \\
\text { metilico }\end{array}$ & $\begin{array}{l}\text { murcha de Fusarium, } \\
\text { podridão-seca }\end{array}$ & sistêmico & divisão celular & alto \\
\hline fluazinam & $\begin{array}{c}\text { rizoctoniose } \\
\text { mofo-branco } \\
\text { sarna-pulverulenta }\end{array}$ & contato & fosforilação oxidativa & baixo \\
\hline procimidona & $\begin{array}{l}\text { Mofo-branco } \\
\text { rizoctoniose }\end{array}$ & translaminar & transdução do sinal & médio a alto \\
\hline piraclostrobina & rizoctoniose & translaminar & $\begin{array}{l}\text { inibidor da respiração } \\
\text { complexo III }\end{array}$ & alto \\
\hline boscalida & Mofo-branco & translaminar & $\begin{array}{c}\text { inibidor da respiração } \\
\text { complexo II }\end{array}$ & médio \\
\hline carboxina +tiram & rizoctoniose & sistêmico/contato & $\begin{array}{c}\text { inibidor da respiração/ } \\
\text { multi-sítio }\end{array}$ & médio \\
\hline
\end{tabular}

Fontes: AGROFIT*, FRAC **02/08/2019 


\section{CONTROLE BIOLÓGICO}

O controle biológico caracteriza-se pela intervenção de organismos não patogênicos no sítio de infecção, de forma a impedir ou limitar a ação do patógeno, bem como aumentar a resistência do hospedeiro. Na cultura da batata, o emprego de Trichoderma sp. utilizado no tratamento de sementes, aplicado no sulco de plantio ou no momento da amontoa, pode reduzir a severidade de doenças de solo como murcha de Fusarium e podridão-seca, mofo-branco, murcha de Verticillium e rizoctoniose.

Estudos têm provado que o uso de formulações de Bacillus subtilis pode ser efetivo no controle do mofo branco e sarna prateada na cultura da batata.

O uso de produtos biológicos pode ser realizado em sistemas orgânicos e em programas de controle integrado. Para resultados efetivos é importante que todas as recomendações do fabricante quanto à dose, condições climáticas adequadas no momento da aplicação e formas de tratamento, entre outras, sejam seguidas.

\section{SISTEMAS ORGÂNICOS}

Em sistemas orgânicos, recomendam-se as medidas de controle citadas anteriormente como: plantio de batatassemente sadias, evitar o plantio em áreas com histórico recente de doenças de solo, uso de cultivares com algum nível de resistência, adubação verde, controle biológico e rotação de culturas.

Pesquisas têm provado que o cultivo de brássicas e algumas gramíneas em rotação de culturas ou como adubo verde tem sido associado a reduções de patógenos de solo na cultura da batata. Essas reduções foram atribuídas à produção de compostos voláteis de enxofre, por meio de um processo conhecido como biofumigação, capaz de alterar a estrutura da comunidade microbiana do solo. Culturas como canola, colza, rabanete, nabo e cevada foram avaliadas para o controle de várias doenças da batata. Em experimentos realizados in vitro e campo, os voláteis liberados de material foliar de brássica e cevada inibiram o crescimento de agentes causais como Rhizoctonia solani, Phytophthora erythroseptica, Globisporangium ultimum e Sclerotinia sclerotiorum. 


\section{REFERÊNCIAS}

ADOLF, B. et al. Fungal, Oomycete, and Plasmodiophorid Diseases of Potato. In: Campos, H.; Ortiz, O. The potato crop. Springer. 2020. p. 307-350.

AGROFIT. http://agrofit.agricultura.gov.br/agrofit_cons/principal_agrofit_cons. Acesso: 02.08.2019.

DIAS, J.A.C.; IAMAUTI, M.T.; FISCHER, I.H. Doenças da Batateira. In: AMORIN, L., REZENDE, J.A.M., BERGAMIN FILHO, A., CAMARGO, L.E.A. (Eds.). Manual de Fitopatologia: doenças das plantas cultivadas. 5. ed. São Paulo: Ceres, 2016. v.2, Cap. 16, p.125-147.

DOMINGUES, R.J.; TÖFOLI, J.G.; AZEVEDO FILHO, J.A.; FERRARI, J.T. Suscetibilidade de cultivares de batata ao olho pardo causado por Cylindrocladium clavatum. Biológico, São Paulo, v.77, n.1, p.17-19, jan./jun., 2015.

FUNGAL DATABASE United States Department of Agriculture. Agricultural Research Service https://nt.ars-grin.gov/fungaldatabases/ Acesso: 06.08.2019.

FUNGICIDE RESISTANCE ACTION COMMITEE. FRAC Code List 2019: Fungal control agents sorted by cross resistance pattern and mode of action (including FRAC Code numbering) Disponível em: https://www.frac.info/docs/default-source/publications/frac-code-list/frac-code-list-2019.pdf?sfvrsn=98ff4b9a_2. Acesso: 02 ago. 2019.

INDEX FUNGORUM. http://www.indexfungorum.org/Names/Names.asp, Acesso: 27.09.2019.

JOHNSON, D.A. Potato Health Management. St. Paul: APS, 2008. 272p.

LARKIN, R.P.; GRIFFIN, T.S. Control of soilborne potato diseases using Brassica green manures. Crop Protection. v. 26, n.7, p. 1067-1077, 2007.

LESLIE, J.F.; SUMMERELL, B.A. The Fusarium laboratory manual. 1. ed. USA: Blackwell Publishing, 2006. $388 \mathrm{p}$.

TÖFOLI, J.G., DOMINGUES, R.J., ZANOTTA, S. Doenças fúngicas da batata. In: SALAS, F.J.S. \& TÖFOLI, J.G. Cultura da batata: pragas e doenças. Instituto Biológico, p.162-208, 2017.

TÖFOLI, J.G.; DOMINGUES, R.J.; FERRARI, J.T.; NOGUEIRA, E.M.C. Doenças fúngicas da cultura da batata: Sintomas, etiologia e manejo. Biológico, São Paulo, v.74, n.1, p.63-74, 2012.

WALE, S.; PLATT, H.W.; CATTLIN, N. Disease pests and disorders of potatoes. Amsterdam: Elsevier, 2008. $179 \mathrm{p}$.

Recebido em: 12/08/2019

Aprovado em: 01/10/2019 


\section{FIGURAS}

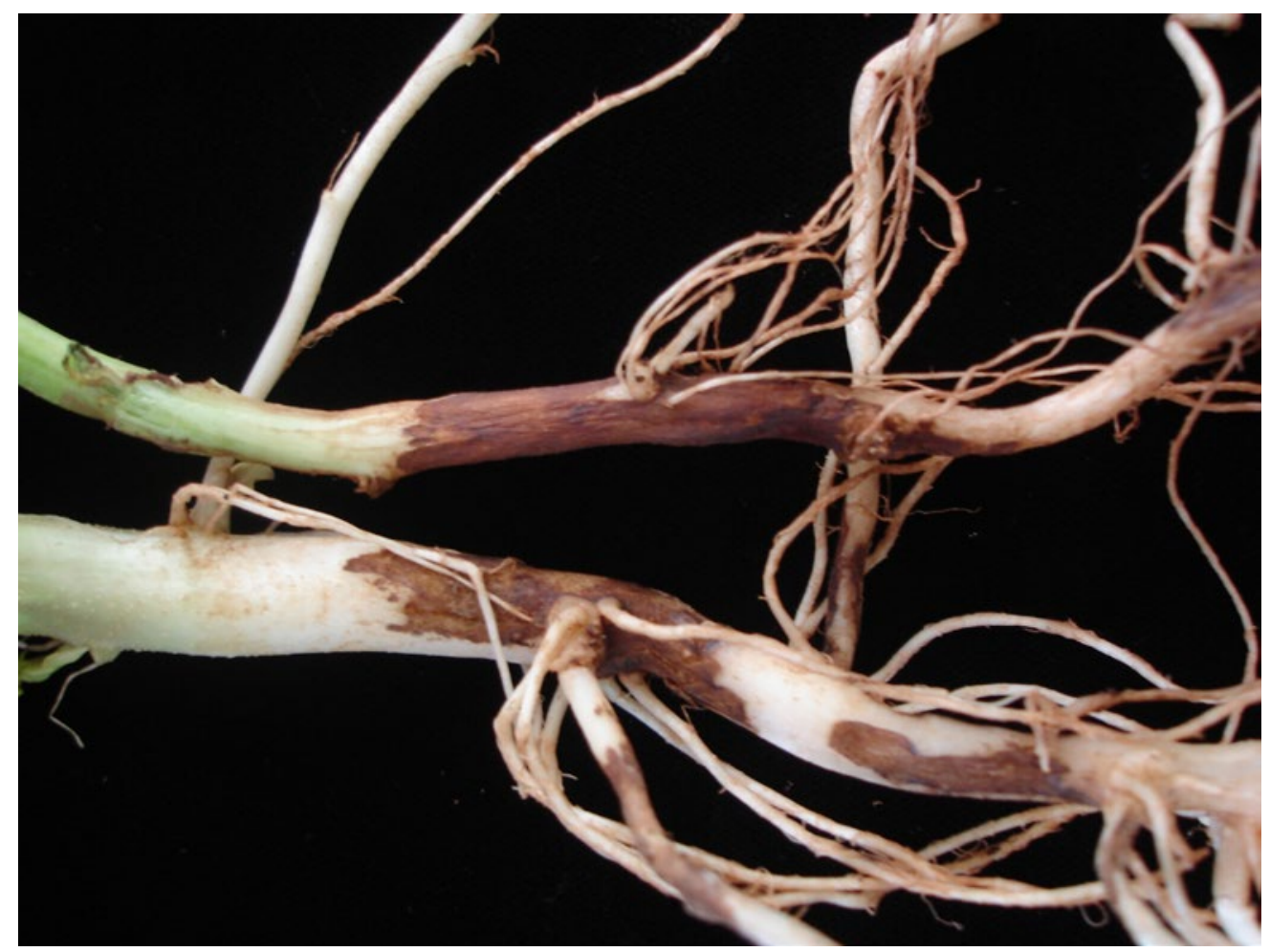

Figura 1. Sintoma de rizoctoniose em plantas jovens de batata. (Autor: Jesus G. Töfoli)

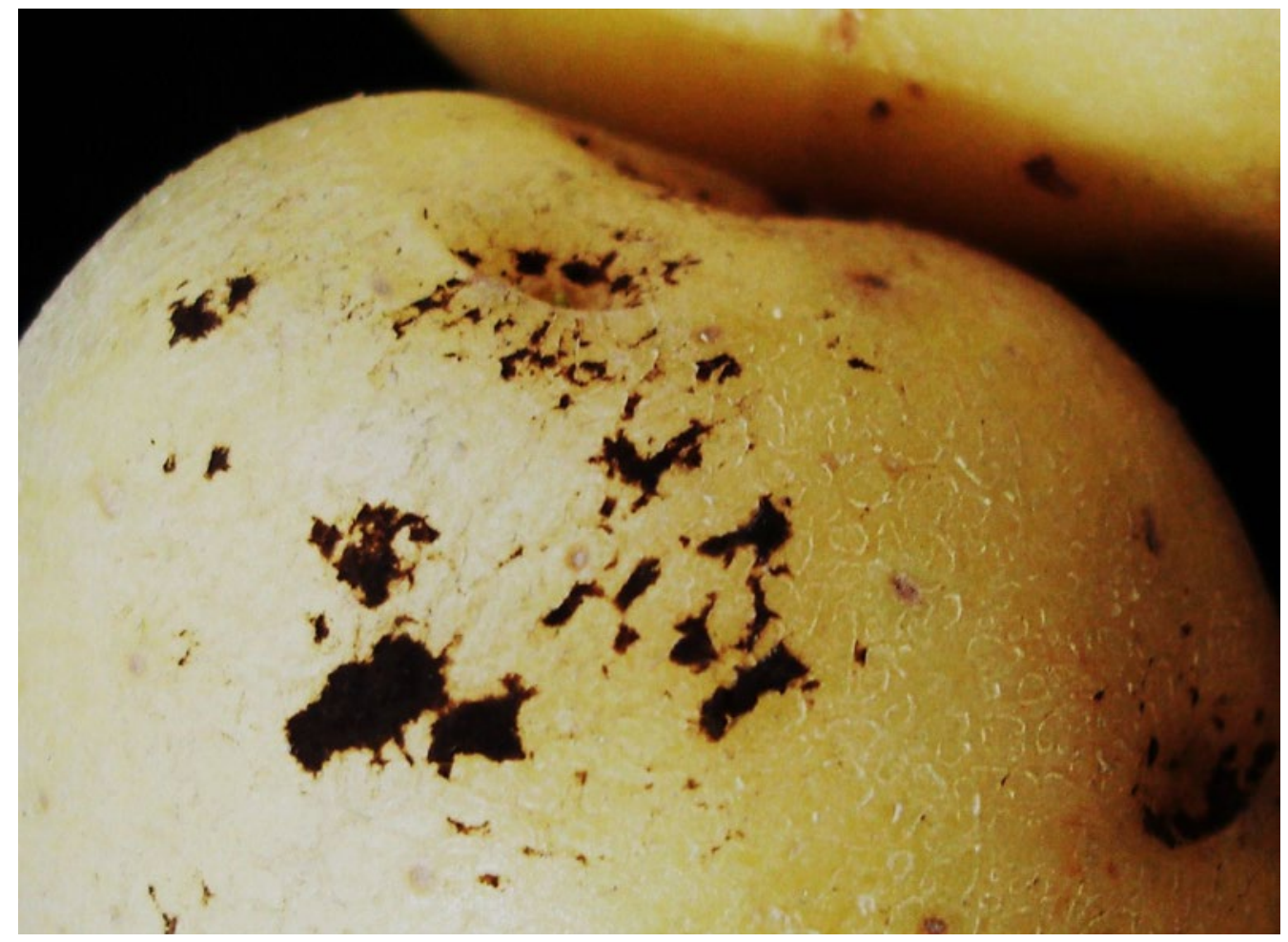

Figura 2. Crosta negra em tubérculo de batata. (Autor: Jesus G. Töfoli) 


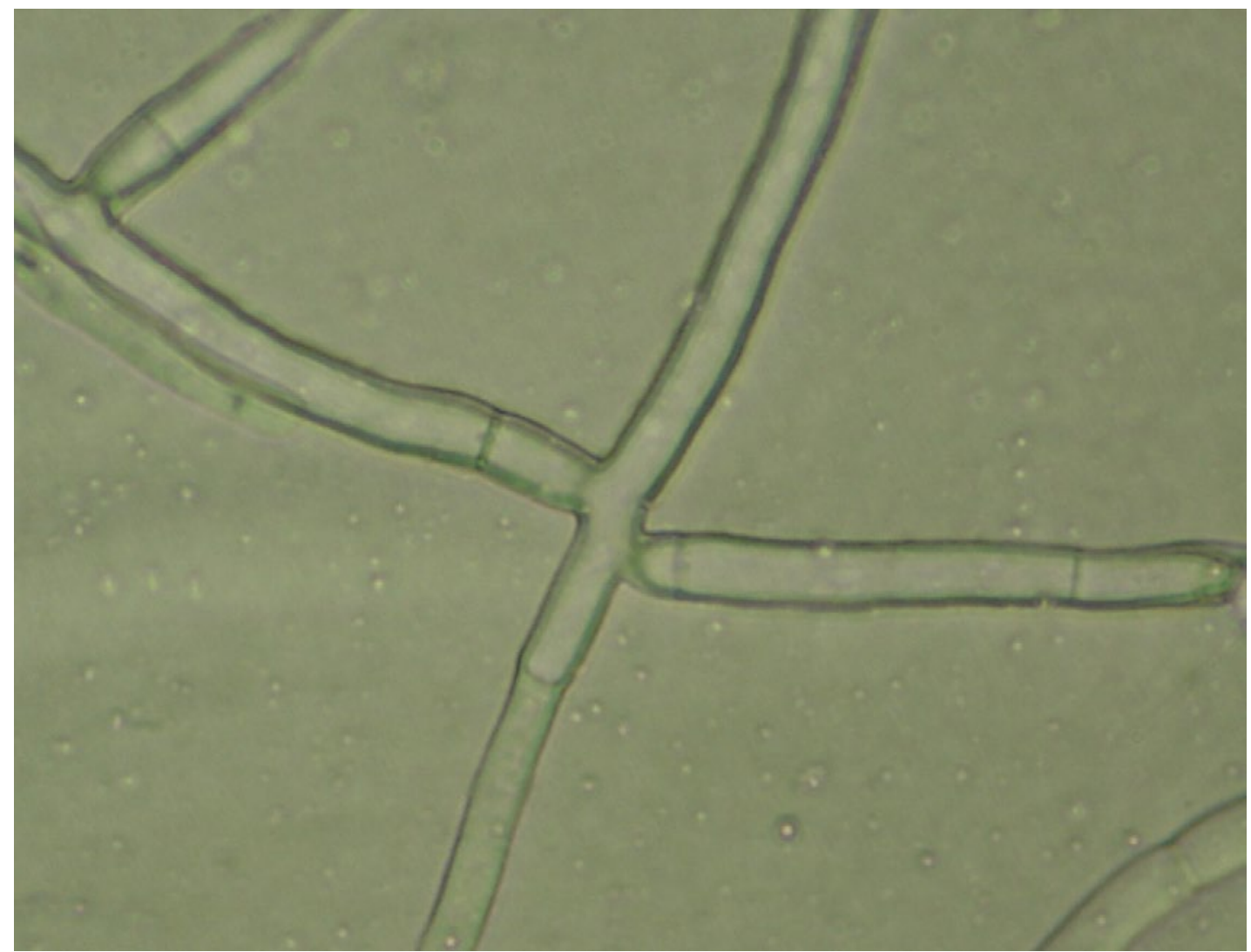

Figura 3. Micélio de Rhizoctonia solani. (Autor: Ricardo J. Domingues)

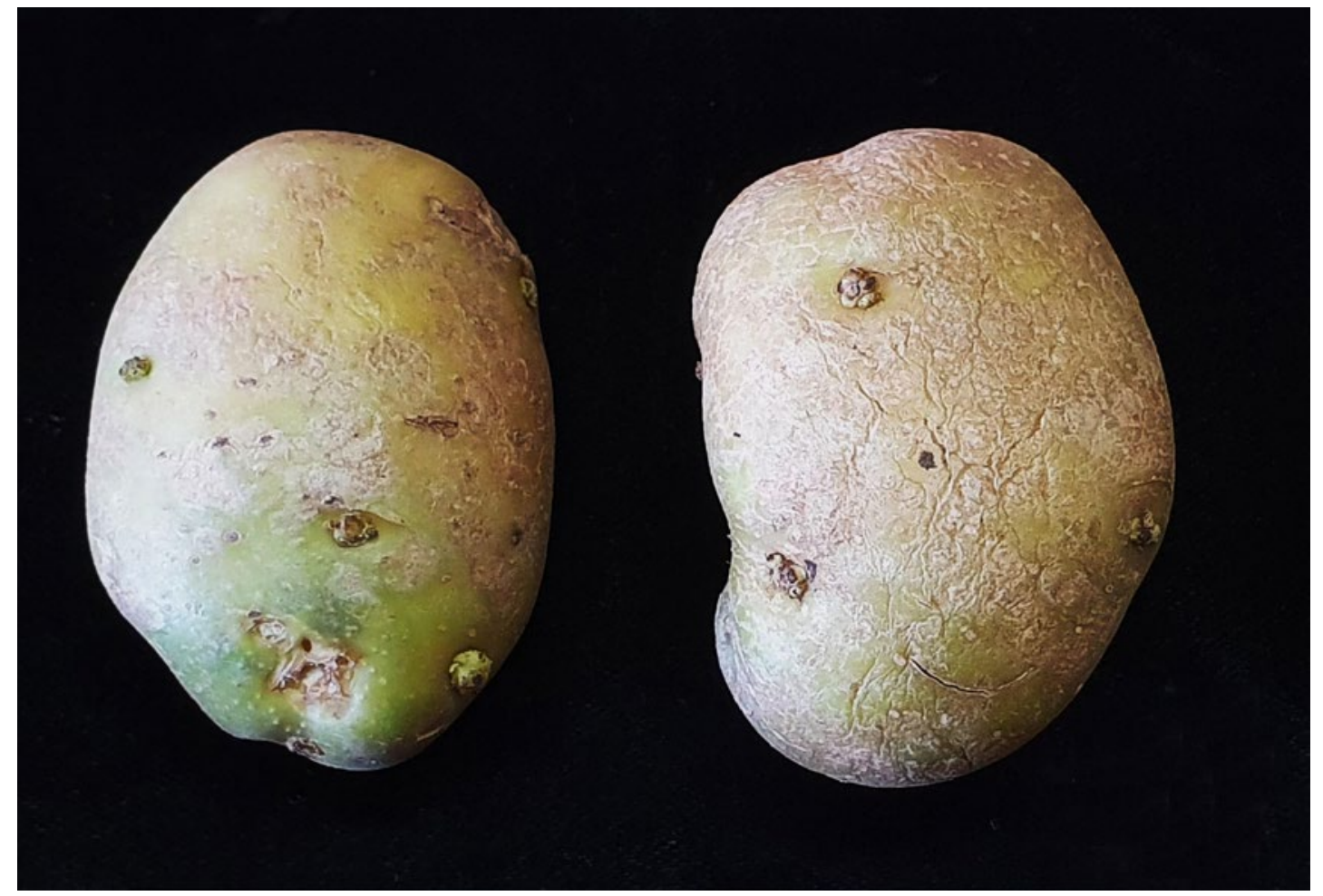

Figura 4. Sarna prateada. (Autora: Josiane T. Ferrari) 


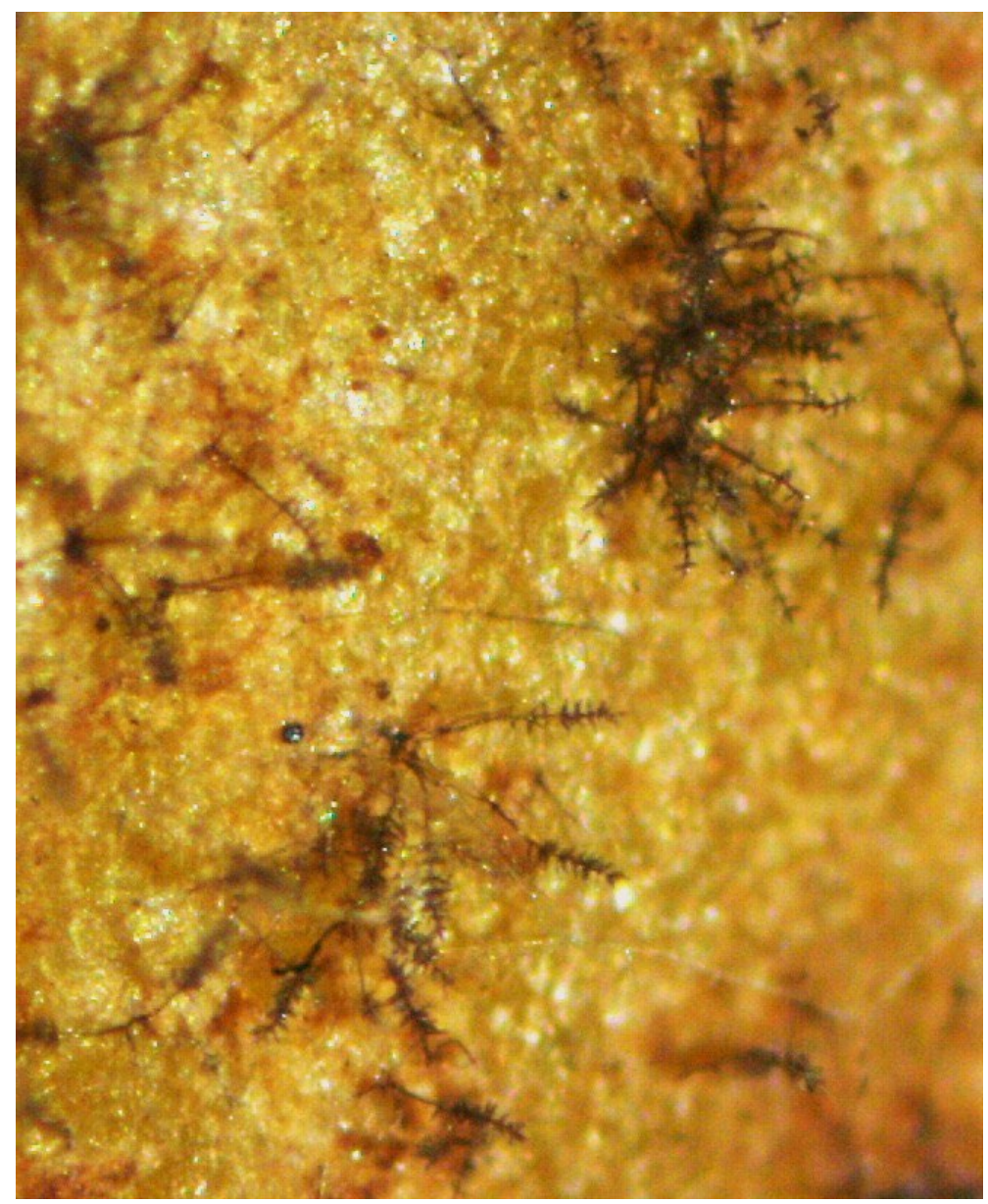

Figura 5. Frutificação de Helminthosporium solani. (Autora: Josiane T. Ferrari)

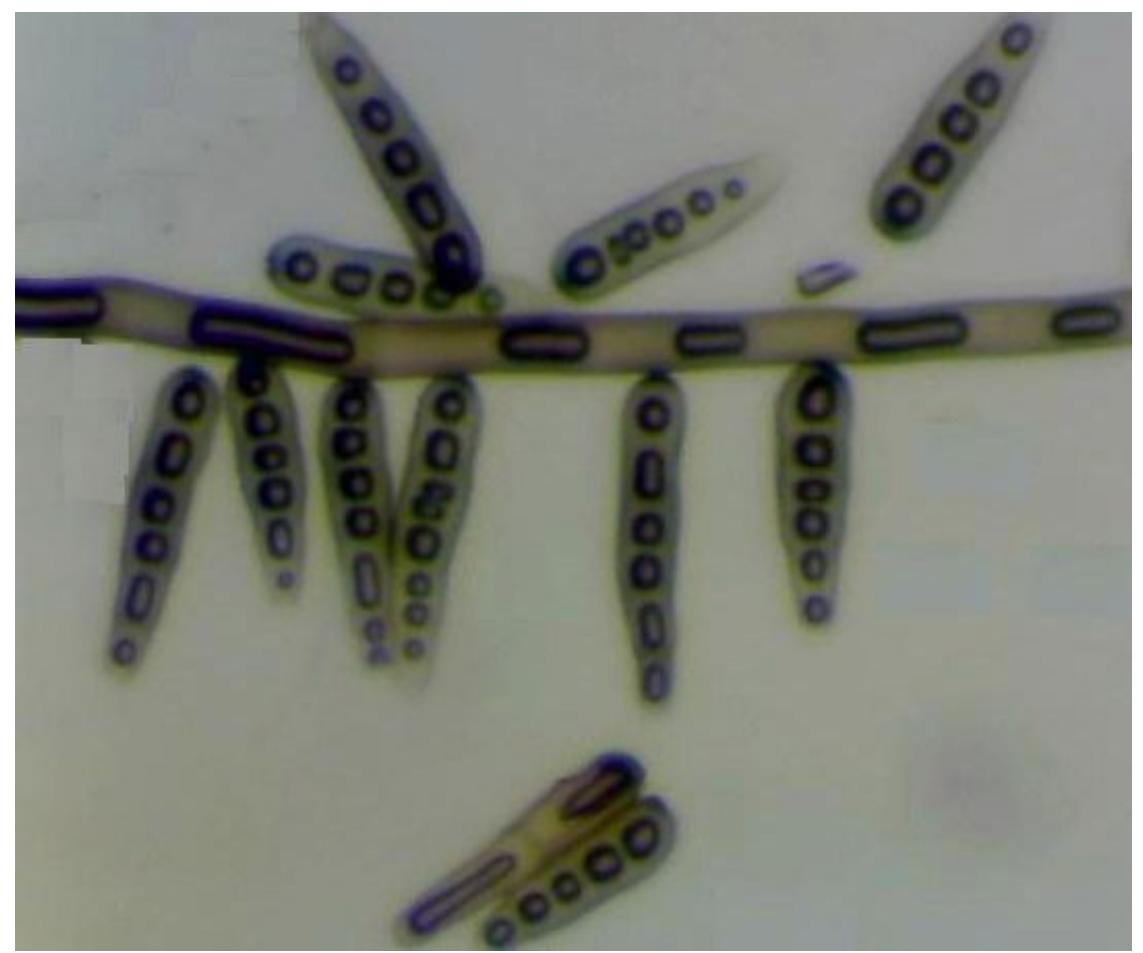

Figura 6. Conídios de Helminthosporium solani. (Autora: Josiane T. Ferrari) 


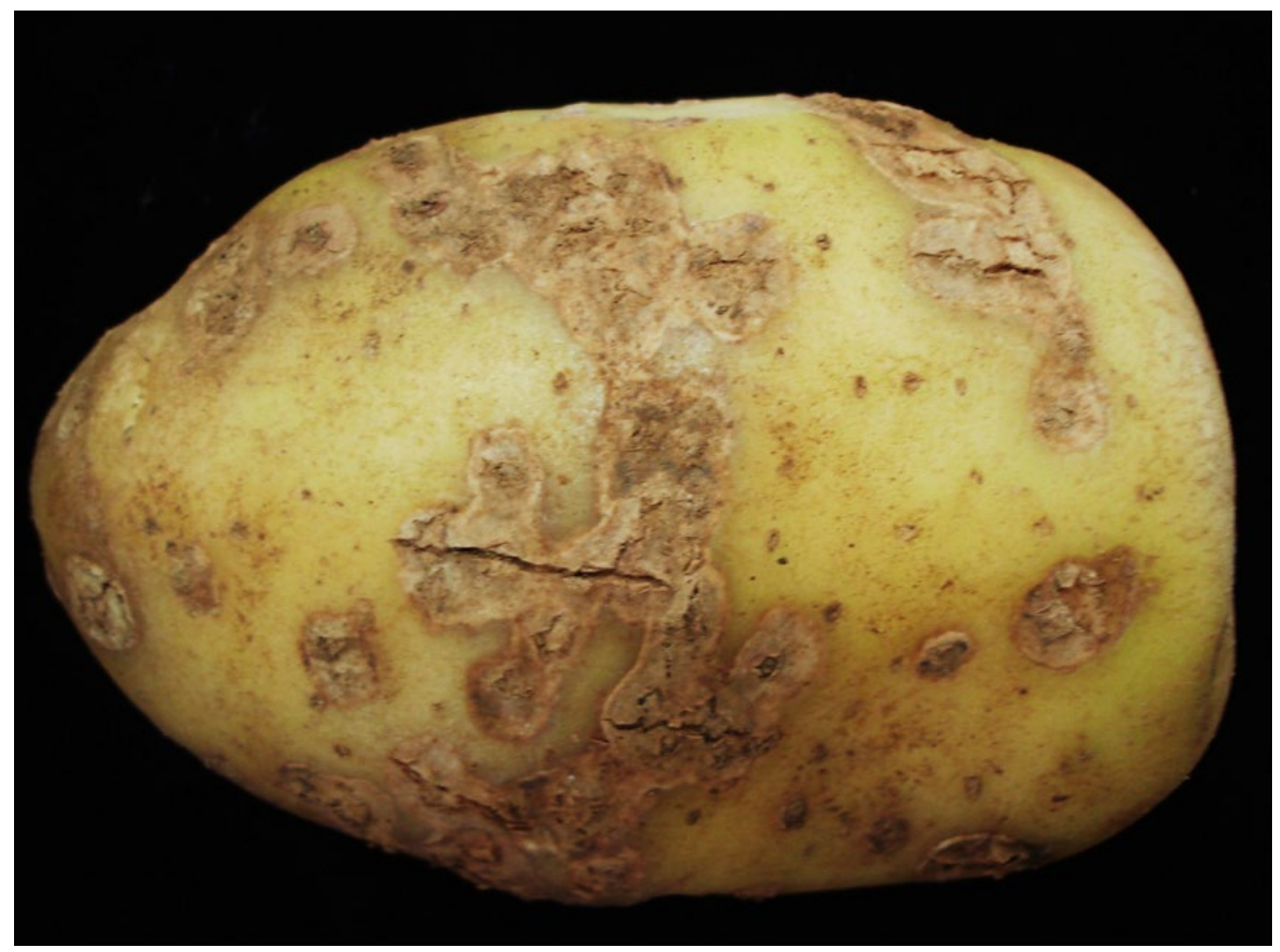

Figura 7. Sarna pulverulenta em tubérculos para consumo. (Autor: Jesus G. Töfoli)

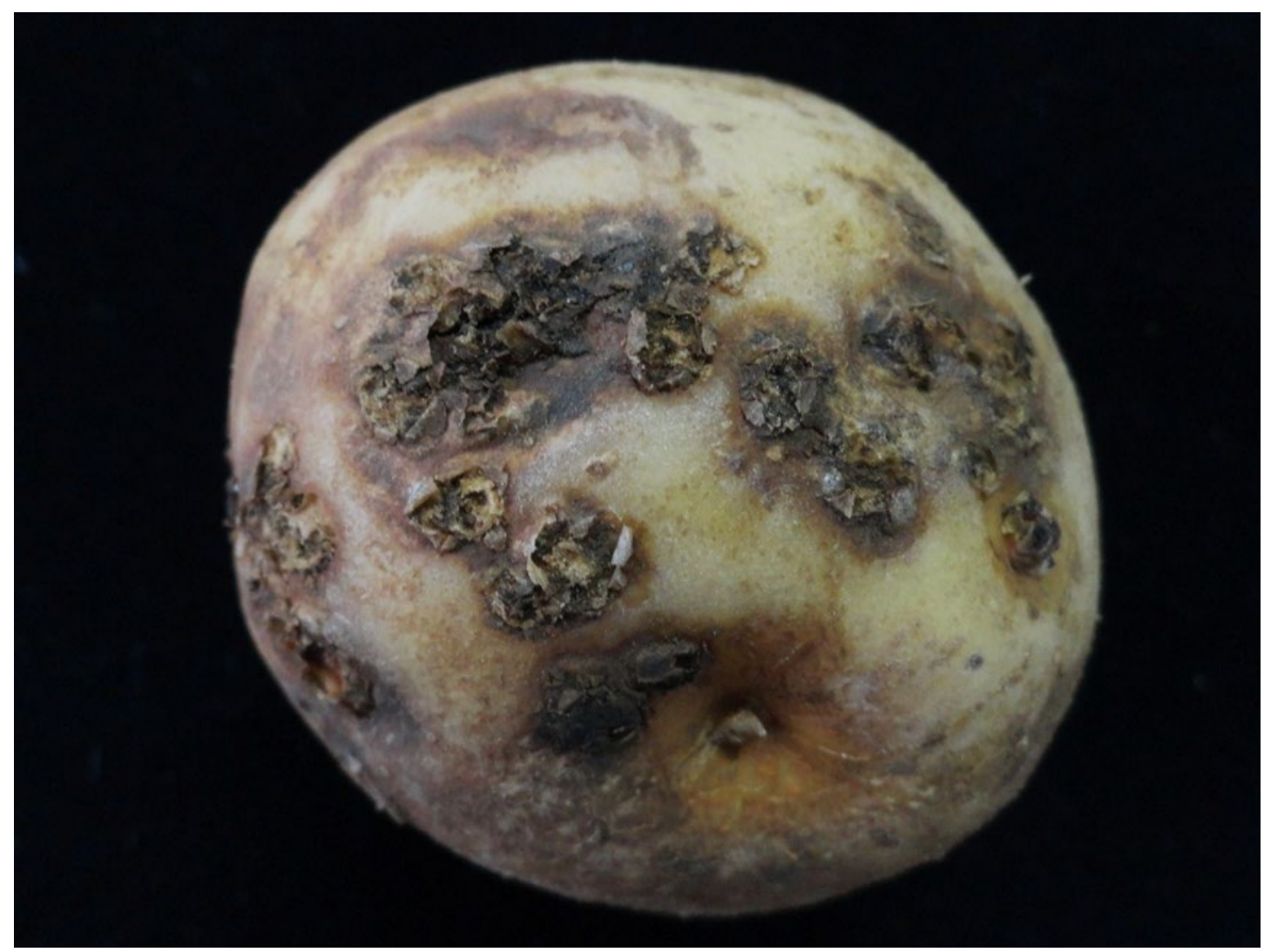

Figura 8. Sarna pulverulenta em batata-semente. (Autor: Jesus G. Töfoli) 


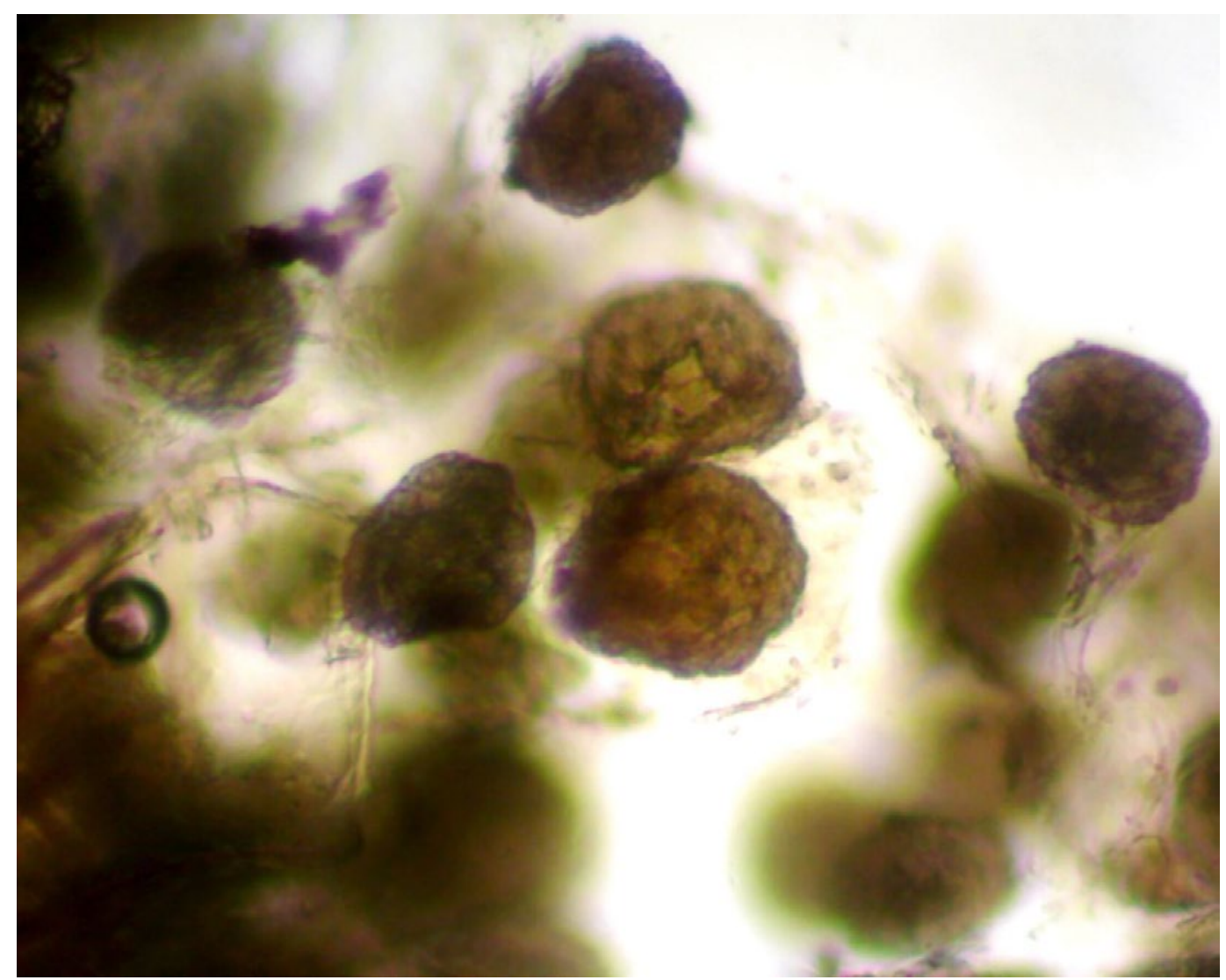

Figura 9. Cistossoros de Spongospora subterranea. (Autor: Ricardo J. Domingues)

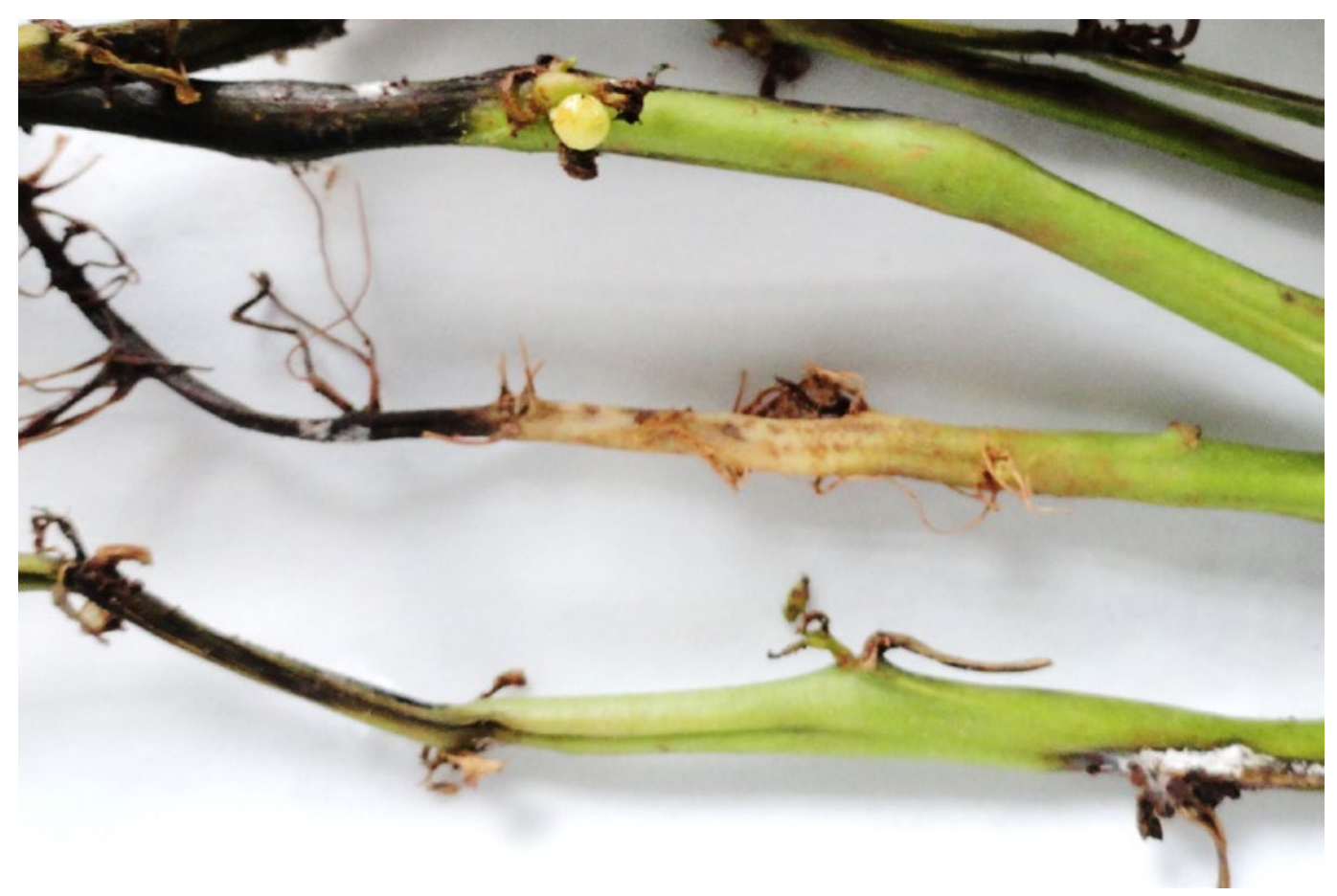

Figura 10. Sintoma de murcha de Fusarium em plantas de batata. (Autor: Jesus G. Töfoli) 


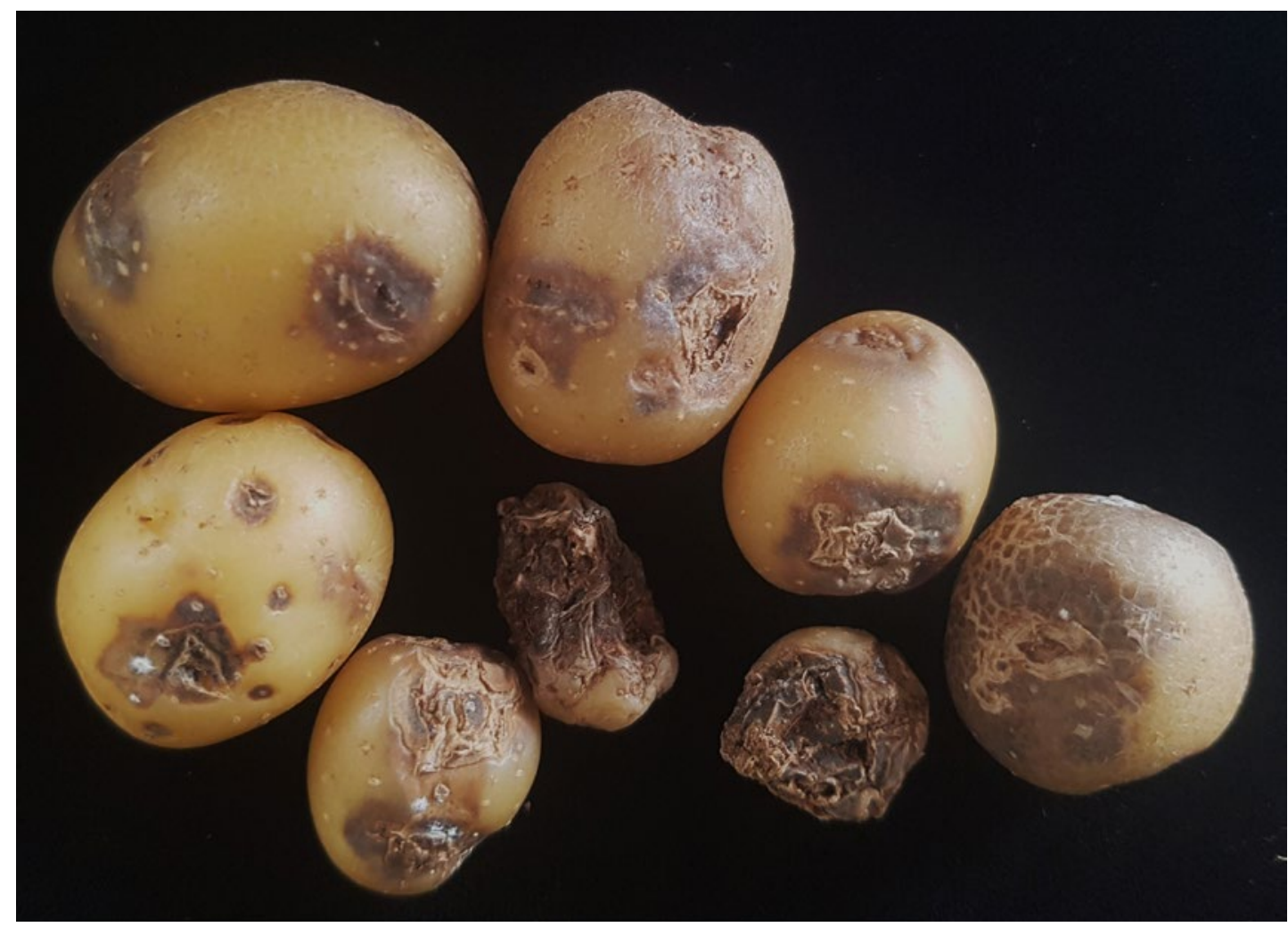

Figura 11. Fusarium spp. em microtubérculos. (Autor: Jesus G. Töfoli)

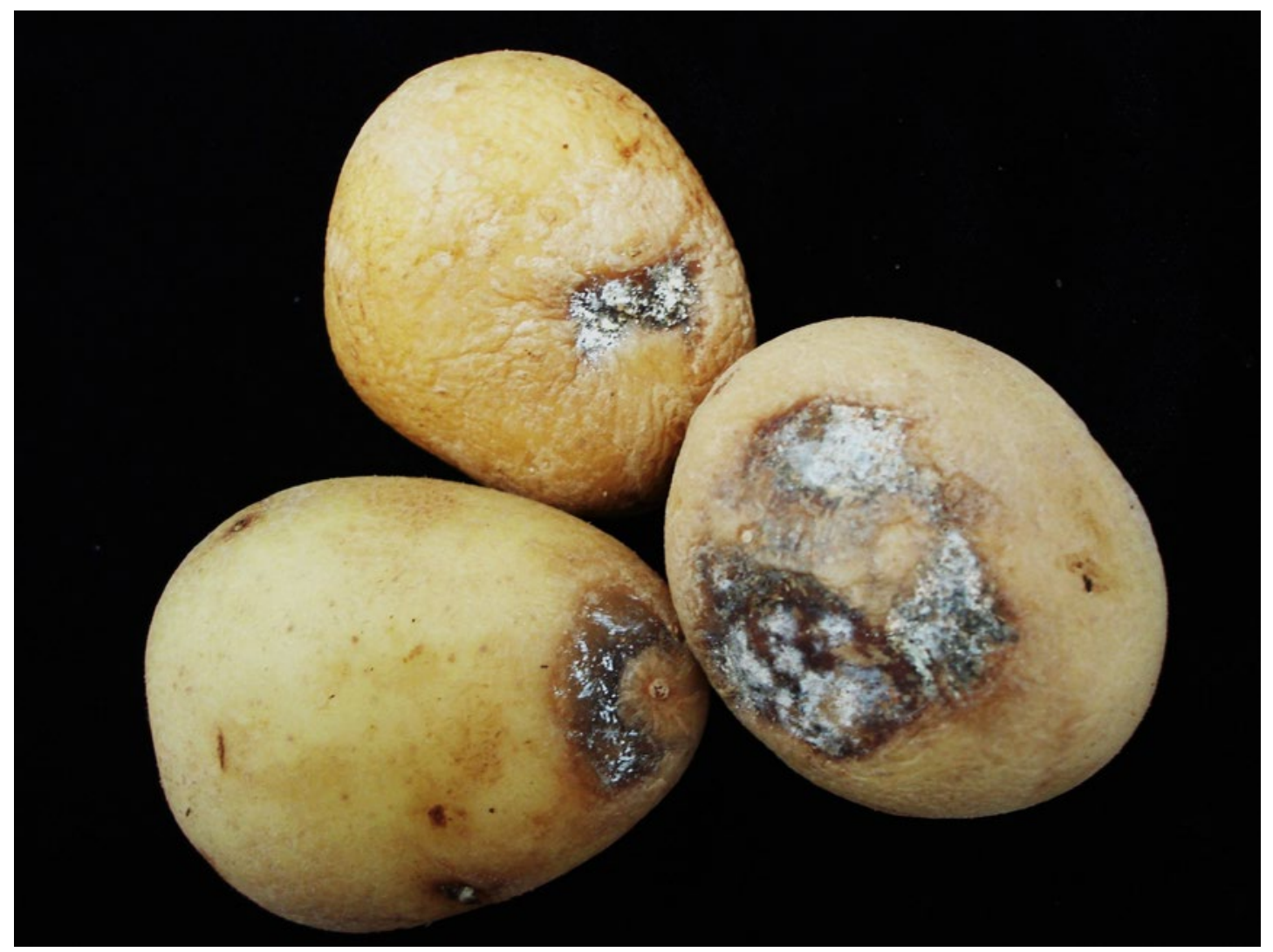

Figura 12. Podridão-seca em batata consumo. (Autor: Jesus G, Töfoli) 


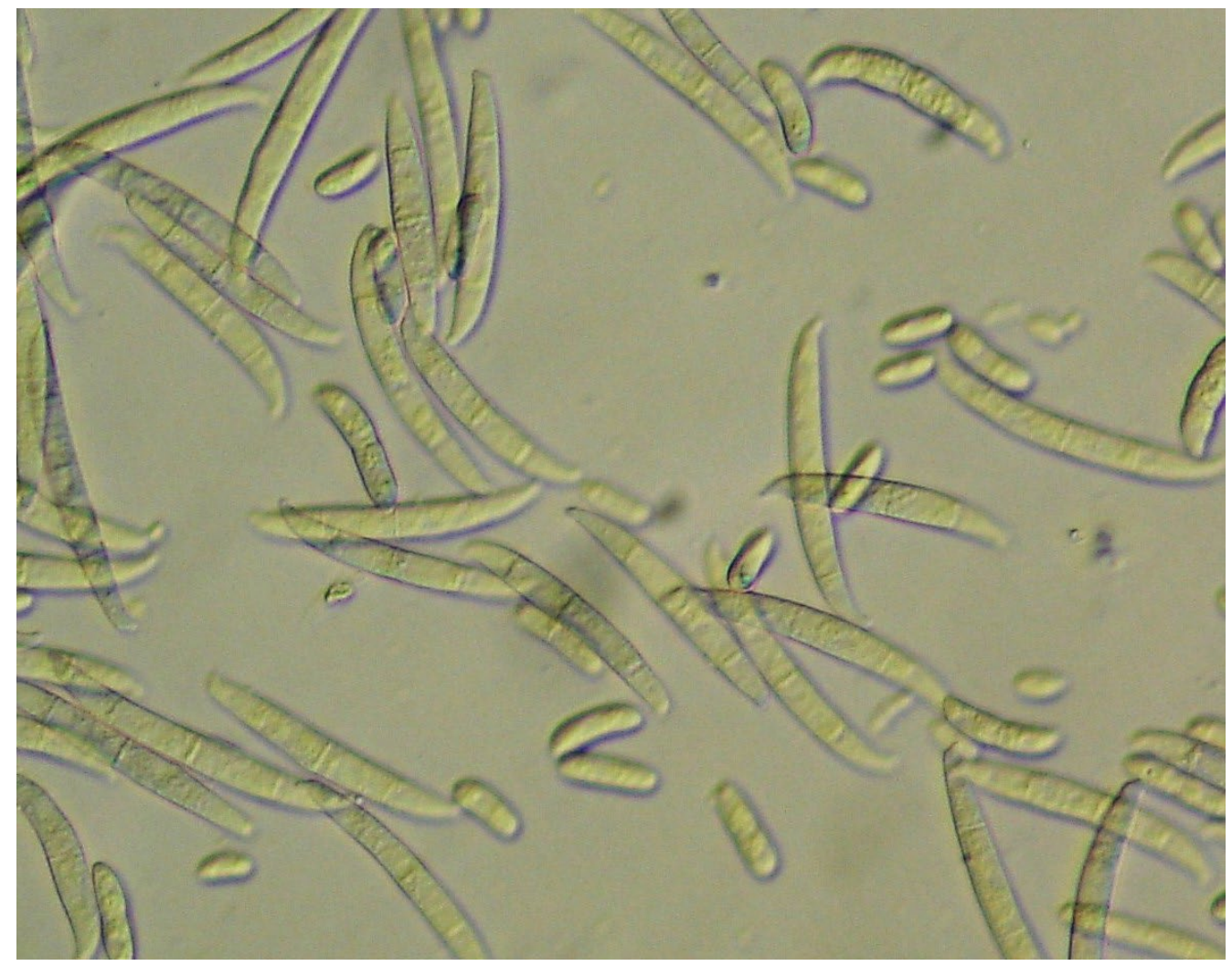

Figura 13. Macro e microconídios de Fusarium oxysporum. (Autor: Ricardo J. Domingues)

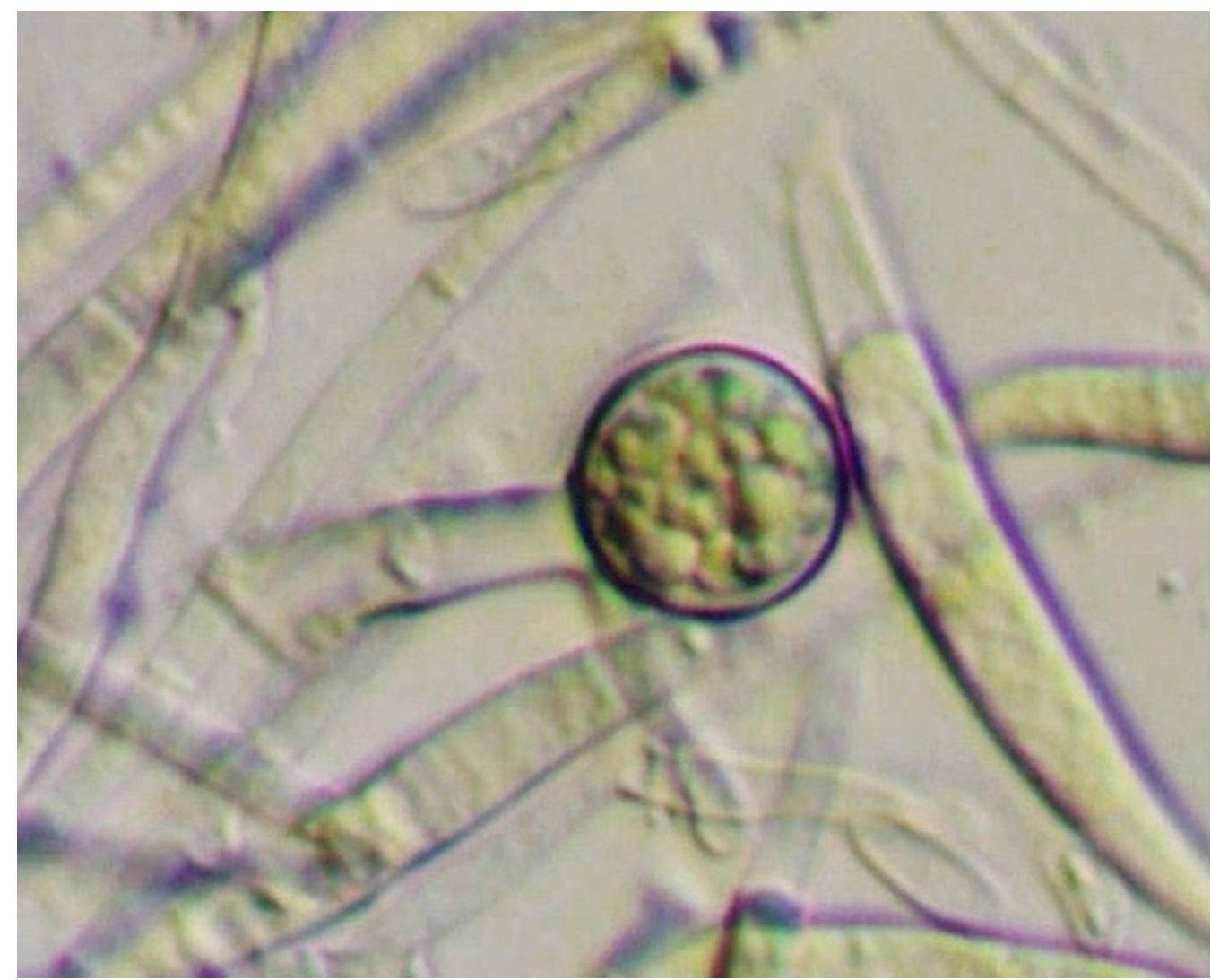

Figura 14. Clamidósporo de Fusarium oxysporum. (Autor: Ricardo J. Domingues) 


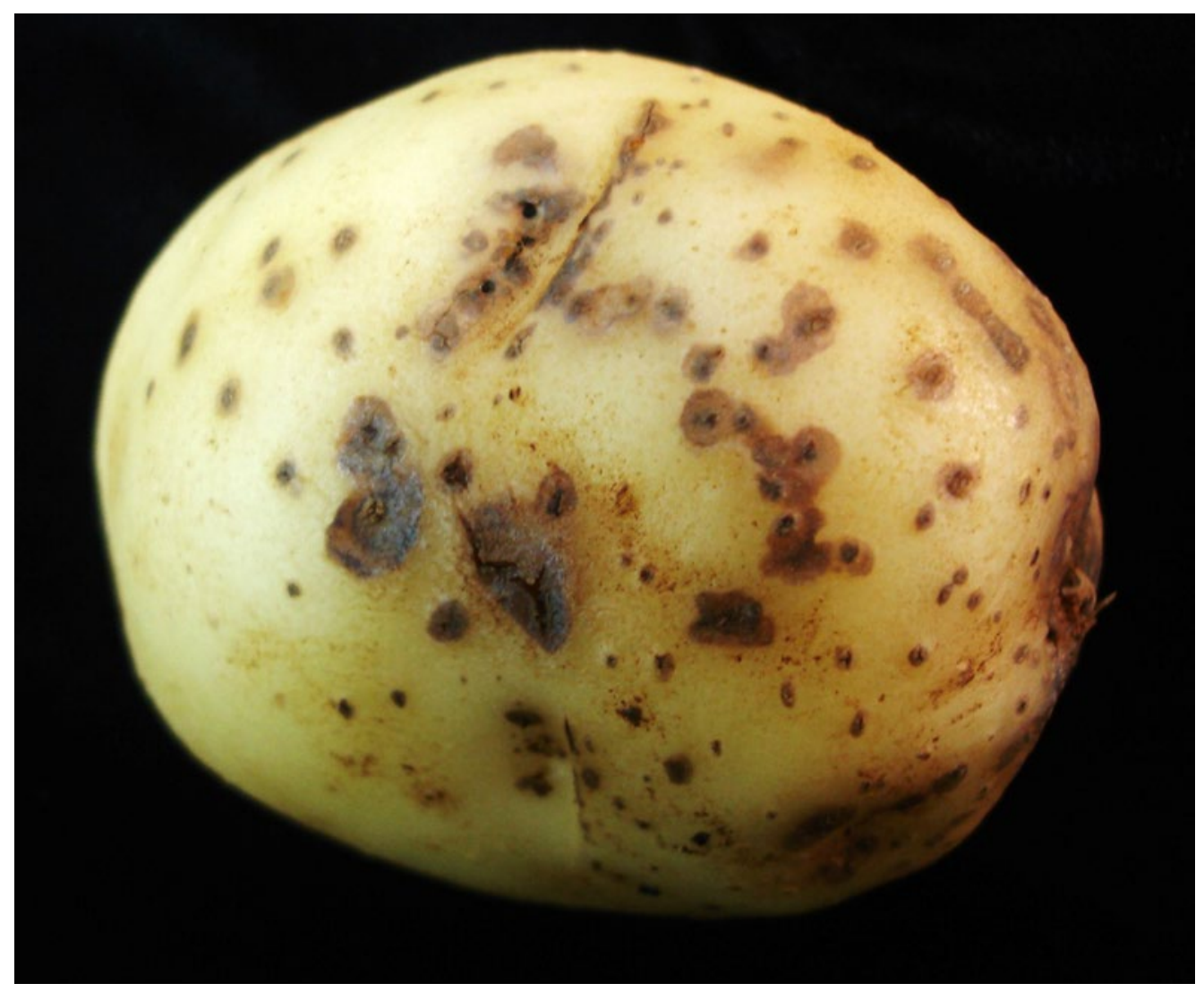

Figura 15. Olho pardo. (Autor: Ricardo J. Domingues)

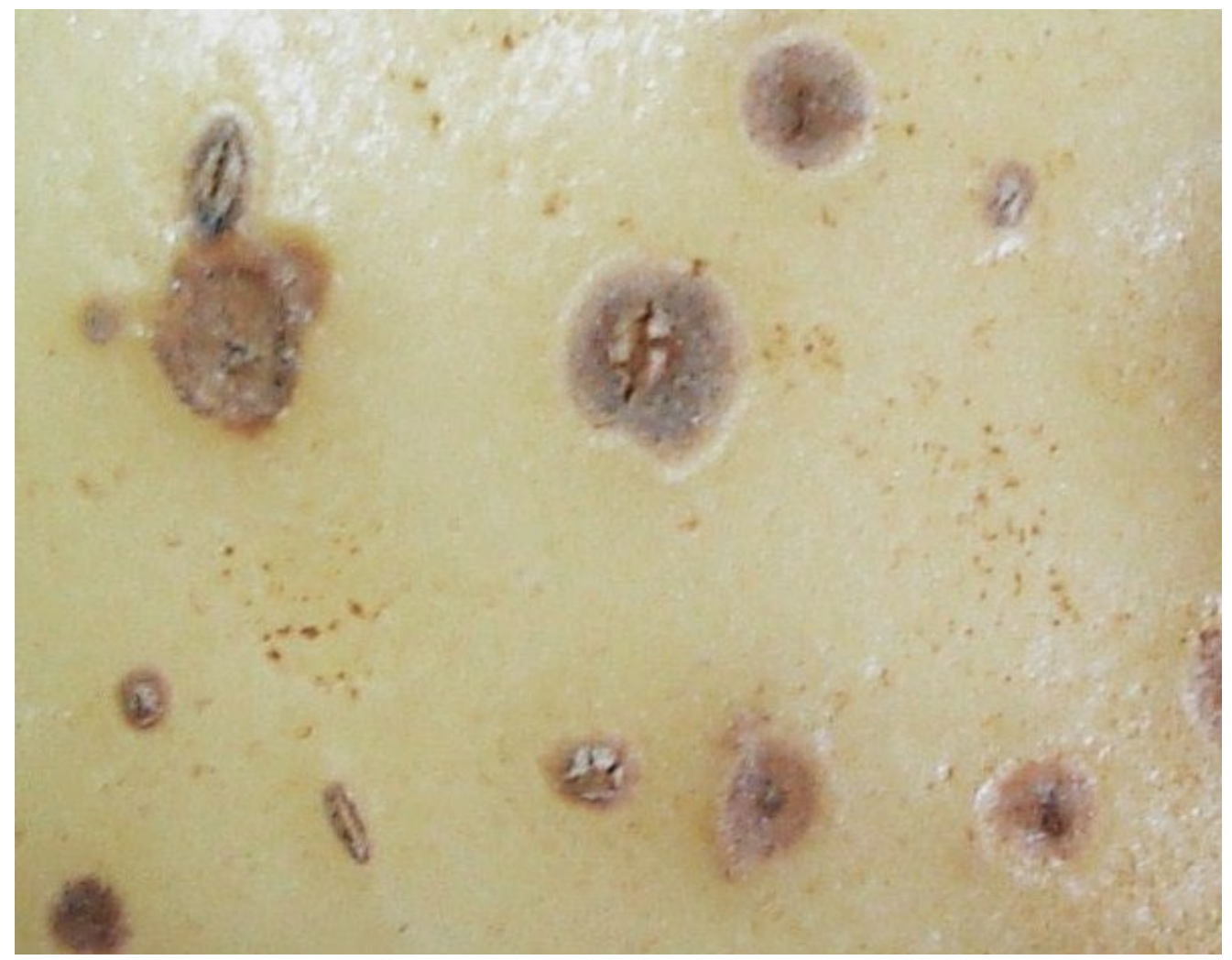

Figura 16. Detalhe de lesões de olho pardo. (Autor: Ricardo J. Domingues) 


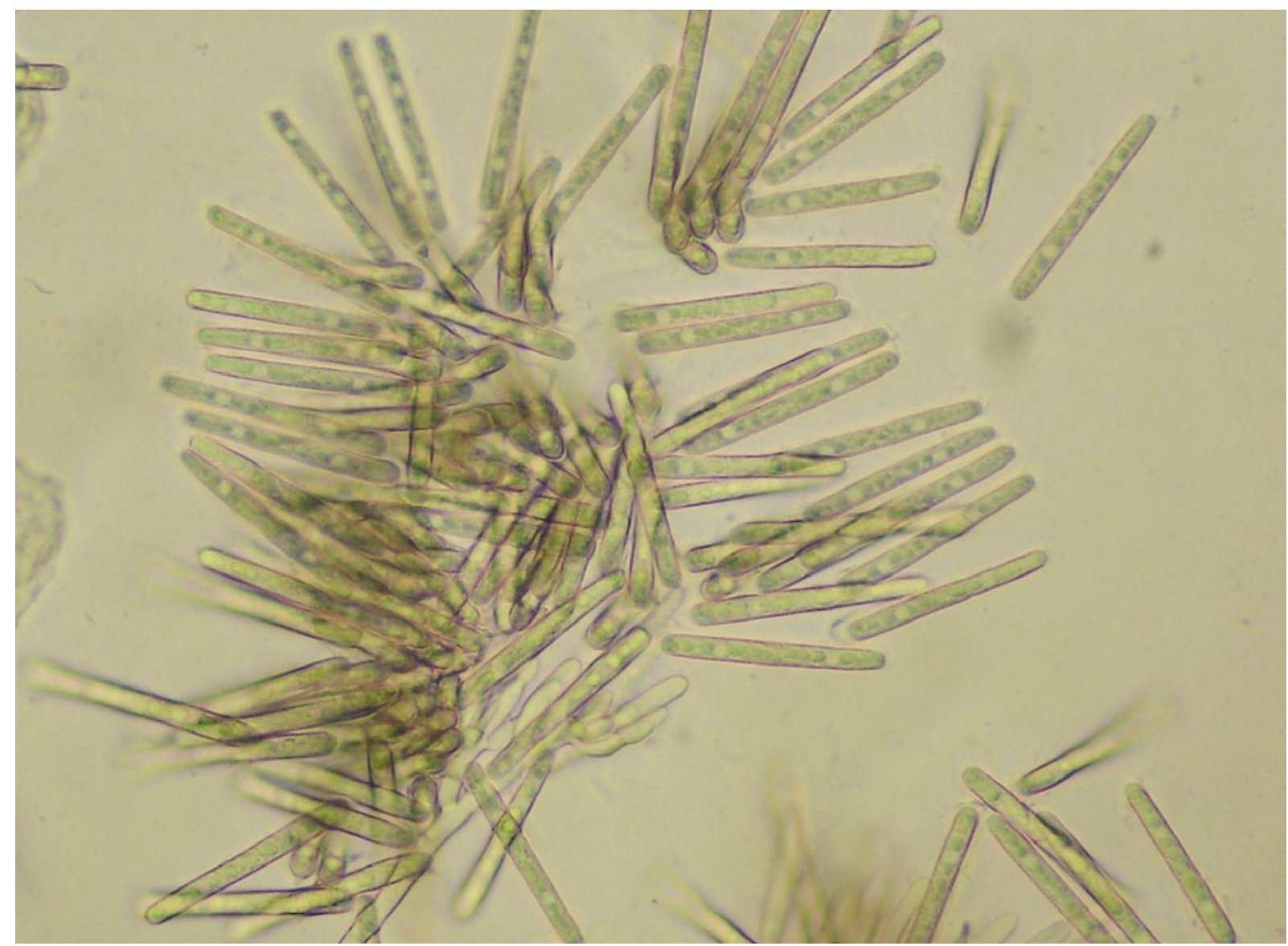

Figura 17. Conídios de Calonectria brassicae. (Autor: Ricardo J. Domingues)

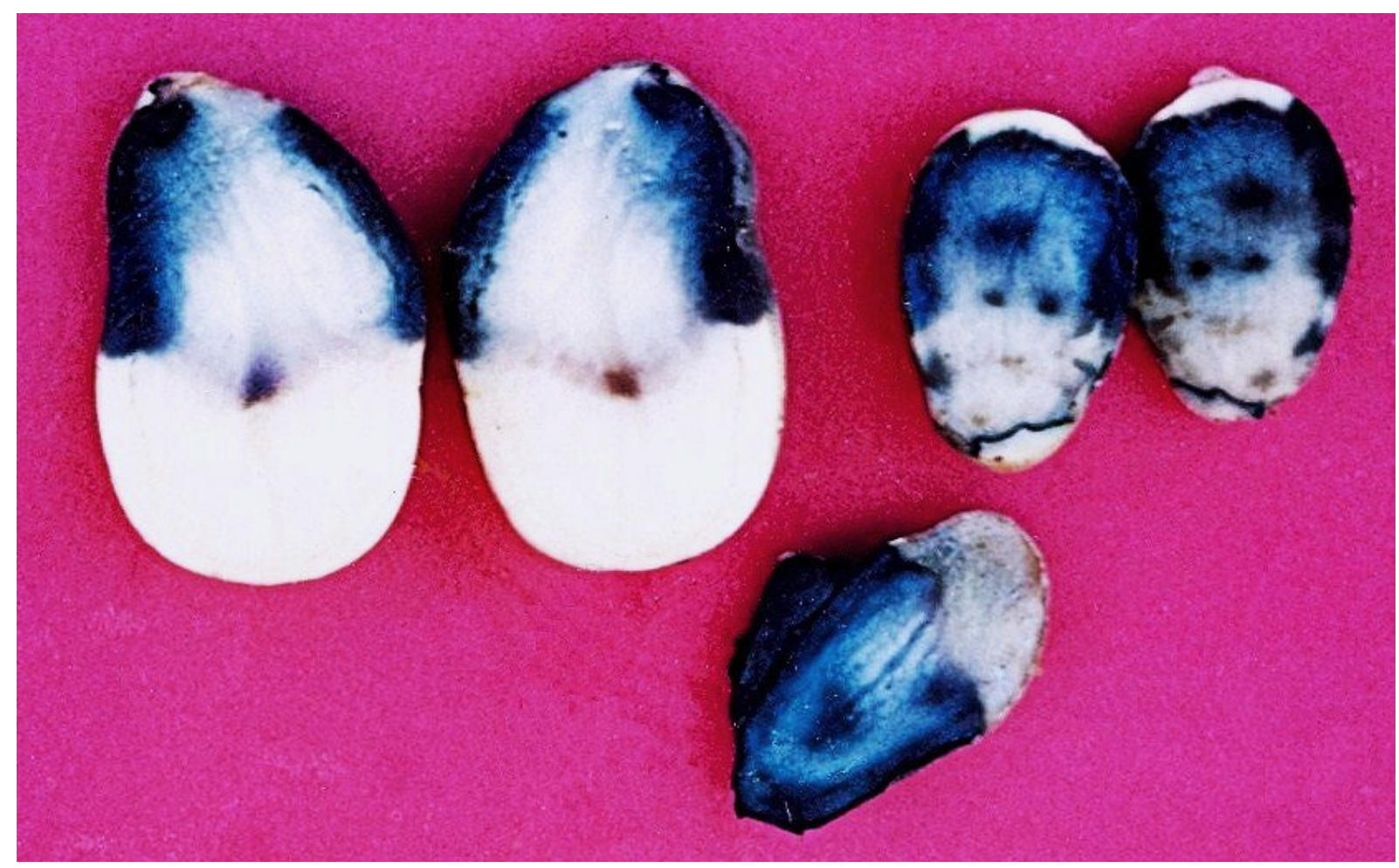

Figura 18. Podridão aquosa em tubérculos. 